OPEN ACCESS

Edited by: Sarah Covshoff, Independent Researcher, Las Vegas, NV, United States

Reviewed by: Colin Osborne,

The University of Sheffield, United Kingdom Isabel Larridon,

Royal Botanic Gardens, Kew, United Kingdom

*Correspondence: Hossein Akhani hakhani@ut.ac.ir

Specialty section: This article was submitted to Plant Systematics and Evolution,

a section of the journal

Frontiers in Plant Science

Received: 17 April 2020

Accepted: 19 August 2020 Published: 05 November 2020

Citation:

Rudov A, Mashkour M, Djamali M and Akhani $\mathrm{H}$ (2020) A Review of $\mathrm{C}_{4}$ Plants in Southwest Asia: An Ecological, Geographical and Taxonomical Analysis of a Region With High Diversity of $\mathrm{C}_{4}$ Eudicots.

Front. Plant Sci. 11:546518. doi: 10.3389/fp/s.2020.546518

\section{A Review of $\mathrm{C}_{4}$ Plants in Southwest Asia: An Ecological, Geographical and Taxonomical Analysis of a Region With High Diversity of $\mathrm{C}_{4}$ Eudicots}

\author{
Alexander Rudov ${ }^{1}$, Marjan Mashkour ${ }^{2}$, Morteza Djamali ${ }^{3}$ and Hossein Akhani ${ }^{1 *}$ \\ 1 Halophytes and $C_{4}$ Plants Research Laboratory, Department of Plant Sciences, School of Biology, College of Sciences, \\ University of Tehran, Tehran, Iran, ${ }^{2}$ Archéozoologie, Archéobotanique: Sociétés, Pratiques et Environnements (AASPE/ \\ UMR7209) - CNRS (Centre national de Recherche Scientifique) et MNHN (Muséum national d'Histoire naturelle), Paris, \\ France, ${ }^{3}$ Institut Méditerranéen de Biodiversité et d'Ecologie (IMBE/UMR7263), Aix Marseille Univ, Avignon Univ, CNRS, IRD, \\ IMBE, Aix-en-Provence, France
}

Southwest Asia is climatically and topographically a highly diverse region in the xeric belt of the Old World. Its diversity of arid habitats and climatic conditions acted as an important area for the evolution and diversification of up to 20 (of 38 known) independent Eudicot $\mathrm{C}_{4}$ origins. Some of these lineages present unique evolutionary strategies like single-cell functioning $\mathrm{C}_{4}$ and $\mathrm{C}_{3}-\mathrm{C}_{4}$ switching mechanisms. The high diversity of $\mathrm{C}_{4}$ taxa in Southwest (SW) Asia is also related to the presence of seven phytogeographic zones including the Irano-Turanian region as a center of diversification of many Caryophyllales lineages and the Somali-Masai region (Southern Oman and Yemen) as a center of diversification for $\mathrm{C}_{4}$ Monocots. Nevertheless, the $\mathrm{C}_{4}$ flora of SW Asia has not received detailed attention. This paper presents a comprehensive review of all known $\mathrm{C}_{4}$ species in the area based on a literature survey, own floristic observations, as well as taxonomic, phylogenetic and herbarium data, and $\delta^{13} \mathrm{C}$-isotope ratio analysis. The resulting checklist includes a total number of 923 (861 native, of which 141 endemic, and 62 introduced) $\mathrm{C}_{4}$ species, composed of 350 Eudicots and 509 Monocots, most of which are therophytic and hemicryptophytic xerophytes with pluriregional and Irano-Turanian distribution. Two hundred thirty-nine new $\delta^{13} \mathrm{C}$-isotope ratios of $\mathrm{C}_{4}$ and $\mathrm{C}_{3}$ plants, as well as some taxonomic changes are presented. An analysis of the distribution of the three main $\mathrm{C}_{4}$ plant families (Chenopodiaceae, Poaceae, and Cyperaceae) in the region in relation to climatic variables indicates that the increase of $\mathrm{C}_{4}$ species follows more or less a latitudinal gradient similar to global patterns, while separate taxonomic groups seem to depend on specific factors as continentality (Chenopodiaceae), average annual temperature (Cyperaceae), and the presence of summer precipitation (Poaceae). An increase of $\mathrm{C}_{4}$ Eudicots in W-E direction even in similar longitudinal belts is explained by a combination of edaphic and climatic conditions. The provided data should encourage a deeper interest in the evolution of $\mathrm{C}_{4}$ lineages in SW Asia and their adaptation to ecological and climatical 
conditions and awaken interest in the importance of local $\mathrm{C}_{4}$ crops, the conservation of threatened $\mathrm{C}_{4}$ taxa, and awareness of human impacts on the rapid environmental changes in the region.

Keywords: $\mathrm{C}_{3}-\mathrm{C}_{4}$ switching plants, $\mathrm{C}_{4}$ crops, Chenopodiaceae, conservation, Irano-Turanian region, Poaceae, single-cell $\mathrm{C}_{4}, \delta^{13} \mathrm{C}$-isotope ratio

\section{INTRODUCTION}

Since its discovery, during the seventh decade of the twentieth century, the $\mathrm{C}_{4}$ photosynthetic pathway has received attention of extensive studies (Hatch, 1999). In contrast to $\mathrm{C}_{3}$ photosynthesis, which evolved under high atmospheric $\mathrm{CO}_{2}$ levels and mesic conditions, $\mathrm{C}_{4}$ photosynthesis developed under low $\mathrm{CO}_{2}$ levels and arid conditions. The climatic changes during the Oligocene (30-25 M.y.a.) and the following Miocene, marked by dropping $\mathrm{CO}_{2}$ levels and increasing seasonality with hot and dry periods and the resulting expansion of arid habitats, favored the convergent evolution and diversification of various $\mathrm{C}_{4}$ lineages (Sage, 2001; Osborne and Beerling, 2006; Christin et al., 2008; Sage, 2016). $\mathrm{C}_{4}$ photosynthesis involves a $\mathrm{CO}_{2}$ concentrating mechanism in hot and arid conditions through the activity of the phosphoenolpyruvate carboxylase (PEPC), an enzyme with a high affinity for $\mathrm{HCO}_{3}^{-}$. The mechanism avoids photorespiration by concentrating $\mathrm{CO}_{2}$ levels around Ribulose-1,5-bisphosphate carboxylase/oxygenase (Rubisco) using a special dual compartmentation named Kranz-anatomy (Sage et al., 2012; Bräutigam and Gowik, 2016). This structure allows fixation of $\mathrm{CO}_{2}$ by PEPC in the mesophyll and its decarboxylation and concentration around Rubisco in the bundle sheath cells. Subsequently, it has been shown, however, that Kranz-anatomy is not always required for $\mathrm{C}_{4}$ photosynthesis in terrestrial plants (Voznesenskaya et al., 2001).

For the classification as a $\mathrm{C}_{4}$ plant, the $\delta^{13} \mathrm{C}$ ratio is a decisive indicator in all known fully functional $\mathrm{C}_{4}$ plants. It is related to differences in the fractionation of stable carbon isotopes ${ }^{12} \mathrm{C}$ and ${ }^{13} \mathrm{C}$ between $\mathrm{C}_{3}$ and $\mathrm{C}_{4}$ plants (O'Leary, 1988; Von Caemmerer et al., 2014). Based on the type of decarboxylating enzymes, $C_{4}$ plants have been distinguished according to their metabolic type in NADdependent malic enzyme (NAD-ME)-type, NADP-dependent malic enzyme (NADP-ME)-type, and phosphoenolpyruvate carboxykinase (PEP-CK)-type (Pyankov et al., 2010). Recent studies, however, question this classification, indicating that $\mathrm{C}_{4}$ plants can be classified in relation to the malate-decarboxylating enzymes as NAD-ME or NADP-ME, while PEP-CK may be considered as an additional decarboxylating pathway (Bräutigam et al., 2014; Wang et al., 2014; Rao and Dixon, 2016).

$\mathrm{C}_{4}$ photosynthesis has been a metabolic revolution within the plant kingdom and a highly favorable metabolic pathway in plants growing under hot and arid conditions. In fact, while $\mathrm{C}_{4}$ plants comprise only $3 \%$ of vascular plants, they account for $25 \%$ of terrestrial photosynthesis (Sage, 2004; Osborne, 2010). Furthermore, this photosynthetic pathway evolved at least 64 times convergently in different plant families (Sage, 2016). Three most numerous $\mathrm{C}_{4}$ taxonomic groups can be distinguished: $\mathrm{C}_{4}$
Poaceae (with around 19 independent $\mathrm{C}_{4}$ clades including ca. 321 genera and over 5,000 species), $\mathrm{C}_{4}$ Cyperaceae (including 6 independent $\mathrm{C}_{4}$ clades in around 7 genera and over 1,300 species) and $\mathrm{C}_{4}$ Caryophyllales [including 24 independent $\mathrm{C}_{4}$ clades within 8 families (namely Amaranthaceae s. str., Aizoaceae, Caryophyllaceae, Chenopodiaceae, Gisekiaceae, Molluginaceae, Polygonaceae, and Portulacaceae] ca. 50 genera and over 1000 species) (Sage, 2016). The most interesting case in Caryophyllales is the particular diversity of independent $\mathrm{C}_{4}$ clades within the Chenopodiaceae family, that may include up to 13 independent $\mathrm{C}_{4}$ clades and 15 different $\mathrm{C}_{4}$ leaf anatomical types (Pyankov et al., 2001; Kadereit et al., 2003; Kadereit et al., 2012; Sage, 2016). [Following Hernandez-Ledesma et al., 2015; Walker et al., 2018, Chenopodiaceae is treated in this article as a separate family and not as a part of Amaranthaceae, although APG III and IV suggest it to be included in Amaranthaceae (APG III (The Angiosperm Phylogeny Group), 2009; APG IV (The Angiosperm Phylogeny Group), 2016)].

Previous studies have shown that different taxonomic groups of $\mathrm{C}_{4}$ plants [e.g., Monocots (Poaceae, Cyperaceae) and Eudicots (Chenopodiaceae)] follow different distributions in relation to climatic variables (Stowe and Teeri, 1978; Pyankov et al., 2010). In the case of the European continent, the distribution of $\mathrm{C}_{4}$ Monocots seems to be related to high temperatures, while the distribution of $\mathrm{C}_{4}$ Chenopodiaceae and several other $\mathrm{C}_{4}$ Eudicot lineages shows a relation to aridity (Pyankov et al., 2010). Similar tendencies can be observed also in other regions. E.g., the adaptation to aridity extends the dominion of $\mathrm{C}_{4}$ Chenopods to the highly continental Gobi desert and over 4,000 $\mathrm{m}$ altitude of the Pamir (Pyankov et al., 2000a). In tropical and subtropical Asia, Africa, Australia, and South America the majority of $\mathrm{C}_{4}$ Poaceae confirm the trend observed in Europe, being mainly distributed in hot climates with the obligatory presence of summer rainfall (Hattersley, 1983; Cabido et al., 2008; Ehleringer et al., 1987; Schulze et al., 1996; Wooler et al., 2001). $\mathrm{C}_{4}$ Cyperceae, finally, have been reported to be abundant in warm tropical temporary wetlands (Stock et al., 2004). The biodiversity of $\mathrm{C}_{4}$ plants has been so far reported for Europe (Pyankov et al., 2010) and China (Wang and Ma, 2016), while further studies on the distribution of $\mathrm{C}_{4}$ plants in relation to climatic and ecological parameters are available for various $\mathrm{C}_{4}$ lineages or specific geographical areas of the Old and New World (Raghavendra and Das, 1976; Teeri and Stowe, 1976; Tieszen et al., 1979; Waller and Lewis, 1979; Winter, 1981; Hattersley, 1983; Ehleringer et al., 1987; Batanouny et al., 1988; Medina et al., 1989; Schulze et al., 1996; Akhani et al., 1997; Rundel et al., 1999; Pyankov et al., 2000a; Wooler et al., 2001; Stock et al., 2004; Cabido et al., 2008; Mantlana et al., 2008). 
The $\mathrm{C}_{4}$ flora of Southwest Asia is of great interest because of the remarkable diversity of $\mathrm{C}_{4}$ Eudicots and discovery of singlecell functioning $\mathrm{C}_{4}$ (Rechinger, 1963-2015; Nikitin and Geldikhanov, 1988; Akhani et al., 1997; Edwards et al., 2004; Akhani and Ghasemkhani, 2007). Southwest (SW) Asia in an extended sense including the Middle East, European parts of Turkey, Transcaucasia, Turkmenistan, Afghanistan, and Pakistan presents a topographically very diverse region.

Southwest and Central Asia have been proposed to be the origin of at least 20 of the 38 accepted $\mathrm{C}_{4}$ Eudicot lineages (Sage, 2011; Kadereit and Freitag, 2011; Sage, 2016). In fact, both regions can be considered an exceptional areas for the evolution and diversity of $\mathrm{C}_{4}$ Eudicots in a predominantly Monocot dominated " $\mathrm{C}_{4}$ world." This and the high diversity of ecological and morphological features and adaptations of SW Asian $\mathrm{C}_{4}$ plants, as well as the quick degradation of the arid regions in the Middle East by improper agriculture, overgrazing, water mismanagement, desertification, and climate change (Motagh et al., 2008; Akhani, $2015 b$ ) and finally the need of detailed information on the $\mathrm{C}_{4}$ taxa of this region, inspired compilation of this work.

The aims of this work are: 1) to present an "as complete as possible" checklist of $\mathrm{C}_{4}$ species of SW Asia, with information on their respective ecological, floristic, and anatomical characteristics, where available; 2) to publish new $\delta^{13} \mathrm{C}$ stable isotope ratios for taxa with previously unpublished isotope data; 3) to analyze the distribution of $\mathrm{C}_{4}$ plants in $\mathrm{SW}$ Asia in relation to climatic variables and to evaluate different adaptations of the three main taxonomic groups of $\mathrm{C}_{4}$ plants (Chenopodiaceae, Cyperaceae, Poaceae) in relation to climate; 4) to discuss shortly the economical and ecological importance of major regionally cultivated or wild growing $\mathrm{C}_{4}$ crops in a region highly affected by climate change and desertification.

The biodiversity of $\mathrm{C}_{4}$ plants of Southwest Asia is of particular interest to comprehend the evolutionary history of $\mathrm{C}_{4}$ plants and the interaction of habitats, biogeographic regions, climate and soil in relation to $\mathrm{C}_{3}-\mathrm{C}_{4}$ domination. This allows to understand and predict future scenarios of the arid belts of the world, affected by global warming.

\section{MATERIAL AND METHODS}

\section{Data Collection and Nomenclature}

In this article, we treated SW Asia in an extended way (Figure 1). The geographical area considered in this article (extended Southwest Asia) includes the territories of the following countries and geographic areas: Afghanistan, Armenia, Azerbaijan, Bahrain, Iran, Iraq, Israel/Palestine, Jordan, Kuwait, Lebanon, Oman, Pakistan, Qatar, Saudi Arabia, Sinai Peninsula, Syria, Turkey, Turkmenistan, United Arab Emirates, and Yemen (Figure 1). The $\mathrm{C}_{4}$ species distribution data, habitat, and altitude preferences used for compilation of the checklist of $\mathrm{C}_{4}$ plants of SW Asia were obtained from standard floras, regional contributions, revisions, monographs, reports, and data bases and electronics sources (Supplementary Appendix Table 1). Data from Herbarium collections were obtained from the Herbarium of $\mathrm{H}$. Akhani
(Halophytes and $\mathrm{C}_{4}$ Plants Research Laboratory, School of Biology, University of Tehran), the Royal Botanic Garden Edinburgh Herbarium (E), and the Herbarium of Russian Academy of Sciences-V. L. Komarov Botanical Institute (LE). Finally, we received some unpublished data such as Cyperaceae of the Arabian Peninsula, kindly provided by Dr. David A. Simpson through personal communications (Royal Botanical Gardens Kew).

The published literature has been screened for all $\mathrm{C}_{4}$ species in the area, their respective habitat, distribution, life form, choro-, morpho-, and ecotypes. Taxonomic treatment and nomenclature of the $\mathrm{C}_{4}$ species were mainly based on global databases such as IPNI (2019) and POWO (2019). The naming of families followed the Angiosperm Phylogeny Group classification (APG IV, 2016) with the exception of the family Chenopodiaceae, which is treated as a separate family and not as a part of Amaranthaceae following Hernandez-Ledesma et al. (2015). The polymorphic genus Calligonum was treated taxonomically in accordance with the taxonomic simplifications proposed by Soskov (2011) and the genus Tribulus according to the simplifications proposed by Thomas and colleagues (Al-Hemaid and Thomas, 1996; Varghese et al., 2006) (see Discussion for further notes). Plants were classified as $\mathrm{C}_{4}$ species based on stable carbon isotope ratios $\left(\delta^{13} \mathrm{C}\right.$-values $)$ as far as previous or own data support, leaf anatomy (presence of Kranz-anatomy), and biochemical subtypes (Supplementary Appendix Table 1). Species with no specific data available, but taxonomically belonging to pure $\mathrm{C}_{4}$ clades, were as well included in the list but marked with $\mathrm{AR}$ (analysis required). The $\mathrm{C}_{4}$ biochemical subtypes are based on published literature (Supplementary Appendix Table 1). In many cases we have extrapolated the "deduced" subtypes based on respective lineage unless there are evidences of multiple subtypes. Furthermore, species with lacking data, belonging to genera with both $\mathrm{C}_{4}$ and $\mathrm{C}_{3}$ clades and unknown attribution were preliminarily excluded from the list and listed separately (Supplementary Table 2). Life form, eco- and morphotype categorization for each species were based on the above-mentioned sources and/or own observations. The consideration of a species as native or introduced was based on distribution data and indications from the standard sources. Chorotypes were proposed based on a species distribution data in relation to the boundaries of the phytochoria. We used the phytogeographical system suggested for SW Asia and Africa by White and Léonard (1991) and considered other references such as Zohary (1973); Takhtajian (1992); Miller and Cope (1996); Djamali et al. (2012); Welk (2015) (Figure 1).

\section{$\delta^{13} \mathrm{C}$ Analysis}

A total of 234 plant samples (Supplementary Appendix Table 1) with unpublished $\delta^{13} \mathrm{C}$-values $\left({ }^{13} \mathrm{C} /{ }^{12} \mathrm{C}\right.$ ratios) have been sampled from herbarium samples. The $\delta^{13} \mathrm{C}$ were analyzed according to the standard procedure relative to PDB (Pee Dee Belemnite) limestone as the carbon isotope standard and calculated according to this formula: $\delta=1,000 \mathrm{x}\left(\mathrm{R}_{\text {sample }} /\right.$ $\mathrm{R}_{\text {standard }}$ - 1) (Osmond et al., 1975; Akhani et al., 2009). The samples have been fine ground using a Retsch ball grinder and transferred in microtubes for isotopic measurement. Each sample was weighted to a mass between 1.50 to $1.90 \mathrm{mg}$ at the 

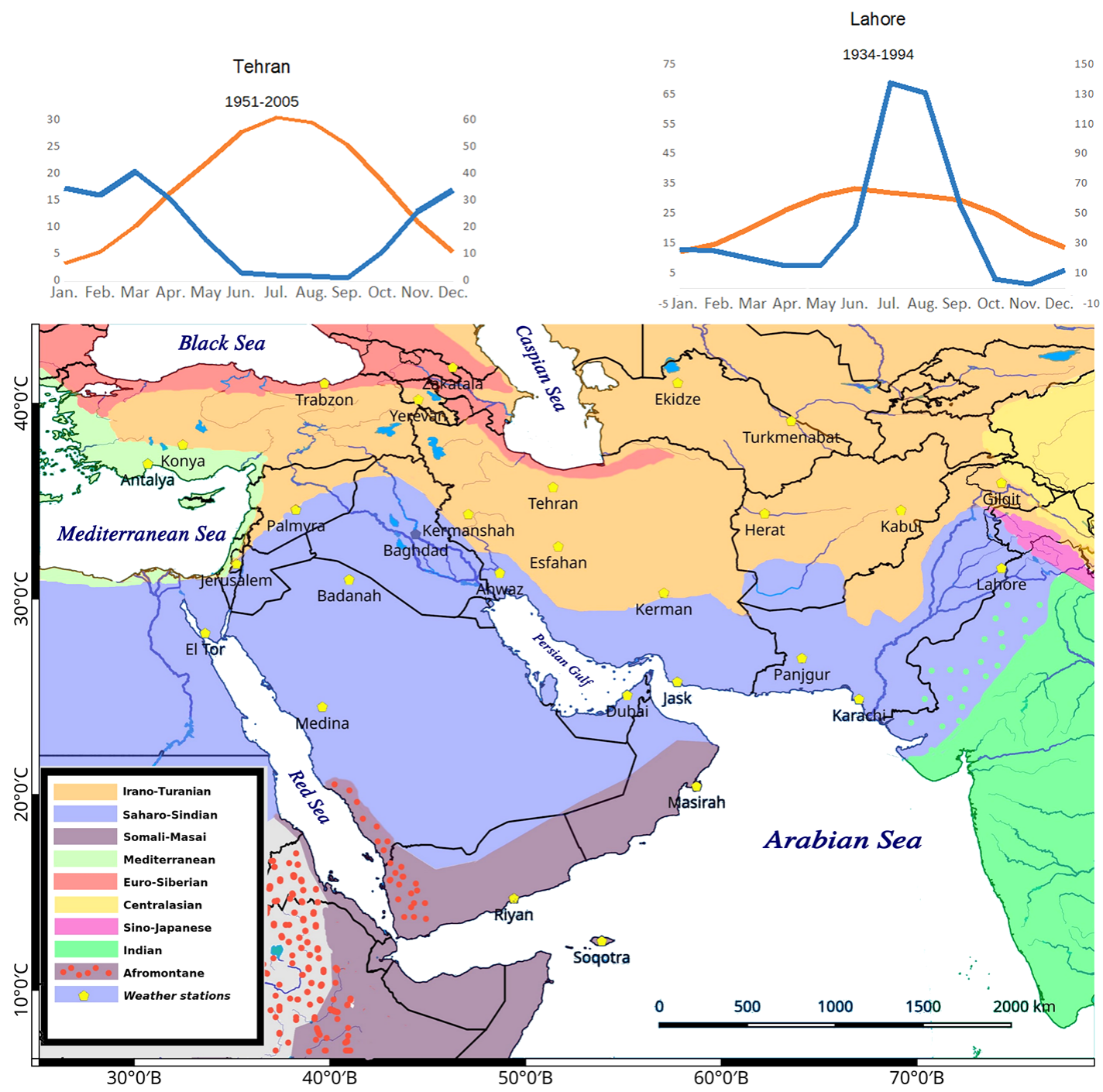

FIGURE 1 | The study area includes Southwest (SW) Asia in an extended sense (Figure 1). Phytogeographic boundaries after White and Léonard (1991). We considered 29 weather stations for the evaluation of distribution of main $\mathrm{C}_{4}$ taxonomic groups in relation to climate. The two extreme climatic conditions showing winter rainfall regime (Tehran) and summer rainfall regime (Lahore) are shown. All other climatic diagrams are depicted in Supplementary Figure $\mathbf{1}$.

SSMIM Mass Spec Lab of the National Museum of Natural History of Paris and burnt in an automated combustion system (EA Flash 2000 Thermo device), interfaced with a DeltaV Advantage Thermo isotope ratio mass spectrometer (continuous flow). The analytical uncertainty within each run estimated from repeated analyses of our laboratory standard (alanine, normalized to IAEA caffeine-600) was lower than $0.08 \%$ o $(\mathrm{k}=1)$ for $\delta^{13} \mathrm{C}$ values.

\section{Climate Data and Statistical Analysis}

For the correlation of $\mathrm{C}_{4}$ taxonomic group distributions within the study area and climatic variables, bioclimatic data were extracted from the Worldwide Bioclimatic Classification System (Rivas-Martinez and Rivas-Saenz, 1996-2019; Djamali et al., 2011). For a few stations we obtained climatic data of the Iranian Meteorological Organization (IRIMO) and Scholte and De Geest (2010) and Raza et al. (2015) (Supplementary Figure 1). Variables, representative for the SW Asia, have been extracted and/or calculated:

a. Mean annual daily temperature (T)

b. Mean annual precipitation $(\mathrm{P})$

c. Continentality index $\left[\mathrm{I}_{\mathrm{c}}=\mathrm{T}_{\max }\right.$ (mean temperature of warmest month) $-\mathrm{T}_{\text {min }}$ (mean temperature of coldest month)]

d. De Martonne Annual Aridity Index $[\mathrm{P} /(\mathrm{T}+10)]$

e. Duration of dry season (number of months with $\mathrm{P}<2 \mathrm{~T}$ )

f. Mean summer precipitation $\left(\mathrm{P}_{\mathrm{s}}-\right.$ mean precipitation of warmest 3 months) 
g. Ombrothermic index of summer $\left(\operatorname{Ios}_{3}=\mathrm{P}_{\mathrm{p} 3} / \mathrm{T}_{\mathrm{p} 3}{ }^{\star} 10\right)$, where $\mathrm{P}_{\mathrm{p} 3}$ is the precipitation of the whole summer and $\mathrm{T}_{\mathrm{p} 3}$ the sum of the mean temperatures for each month of the summer).

The distribution and diversity of $\mathrm{C}_{4}$ plants in relation to climatic variables (annual mean daily temperature, annual mean precipitation, De Martonne aridity index, continentality index, mean summer precipitation, duration of dry season, and ombrothermic index of summer) has been calculated by linear correlation analysis. The correlation is considering the number of total $\mathrm{C}_{4}$ plant species, as well as the numerically and ecologically most important taxonomic groups of $\mathrm{C}_{4}$ plants, e.g., number of $\mathrm{C}_{4}$ Poaceae, $\mathrm{C}_{4}$ Cyperaceae and $\mathrm{C}_{4}$ Chenopodiaceae, and the $\mathrm{C}_{4}$ Monocot/Eudicot ratio. The data have been imported into "OriginPro," which has been used to calculate the linear correlation and Pearson correlation coefficient and for graphical design (Origin Pro, 2017).

\section{RESULTS}

A complete list of all SW Asian $\mathrm{C}_{4}$ species with life form, chorotype, ecotypes, $\delta^{13} \mathrm{C}$-values, metabolic and $\mathrm{Kranz}$ anatomical subtypes is presented in Supplementary Appendix Table 1.

\section{General Statistics}

A total number of 923 (861 native and 62 introduced) $\mathrm{C}_{4}$ species belonging to 166 genera, 48 independent $C_{4}$ lineages, 19 families, and 9 orders have been known from extended SW Asia (Supplementary Appendix Table 1, Figure 1). For the taxonomic diversity of SW Asian $\mathrm{C}_{4}$ plants view Figure 2 .

In the case of Polycarpaea (a polyphyletic genus with both $\mathrm{C}_{3}$ and $\mathrm{C}_{4}$ species), we have only included one species in our list, considering the fact that we could not verify the photosynthetic pathway of seven additional species, reported from the area (mostly from Socotra). A list of these species is given in the Supplementary Table 2.

\section{Distribution of $\mathrm{C}_{4}$ Species by Country}

The number of native and introduced $\mathrm{C}_{4}$ species in individual SW Asian countries/regions and respective Monocot/Eudicot proportions are shown in Figures $\mathbf{3}$ and $\mathbf{4}$ respectively. The highest diversity of $\mathrm{C}_{4}$ plants has been documented for Pakistan (account for $43 \%$ of all known native SW Asian species), Yemen (38\%), Iran (36\%), Saudi Arabia (36\%), Afghanistan (30\%), and Oman (28\%), respectively. The differences in the proportion of $\mathrm{C}_{4}$ Monocot/Eudicots allowed us to categorize countries into three groups: 1) countries with remarkably high percentage of $\mathrm{C}_{4}$ Eudicots, such as Turkmenistan and Iran; 2) countries with more

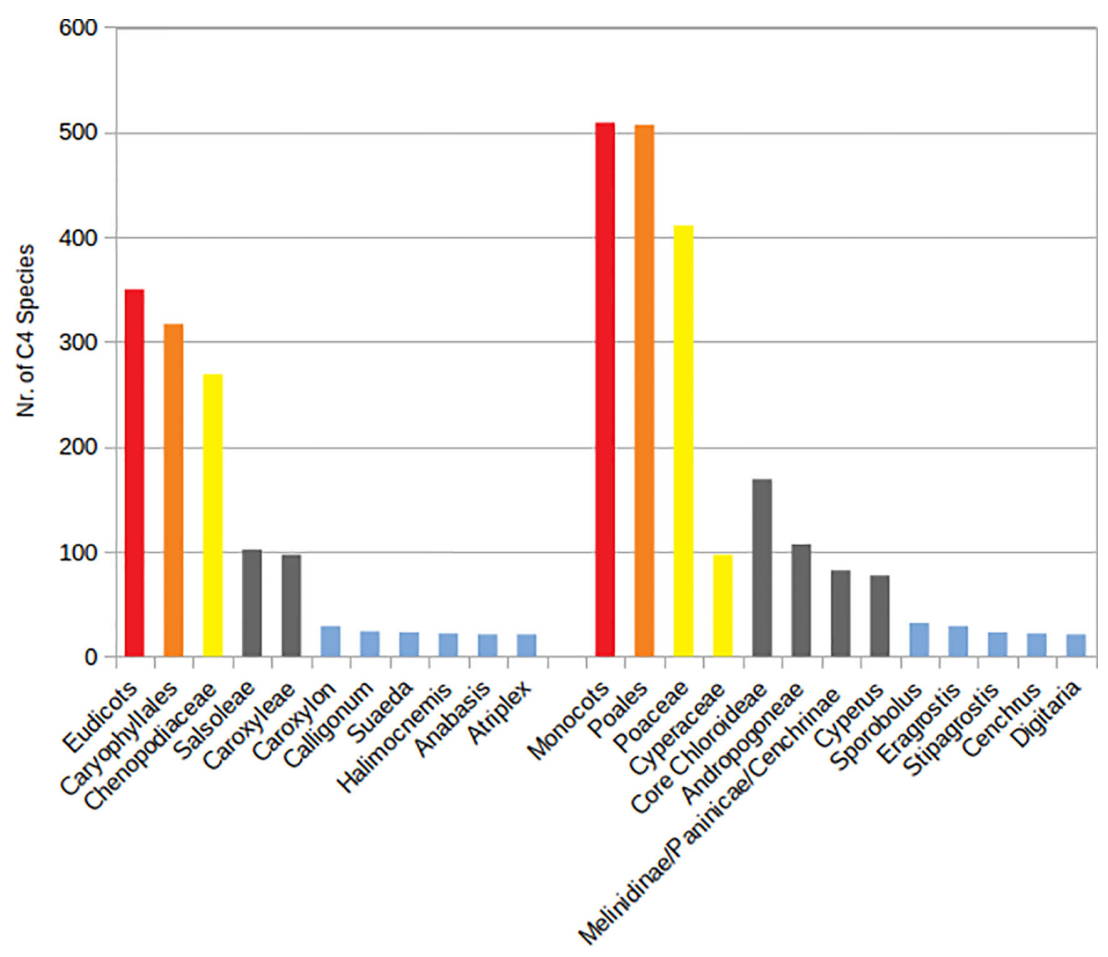

FIGURE 2 | Main taxonomic groups of Southwest (SW) Asian $\mathrm{C}_{4}$ plants. Red-clades, orange-species richest orders, yellow-species richest families, grayspecies richest independent $\mathrm{C}_{4}$ lineages, blue-genera with more than 20 species. 


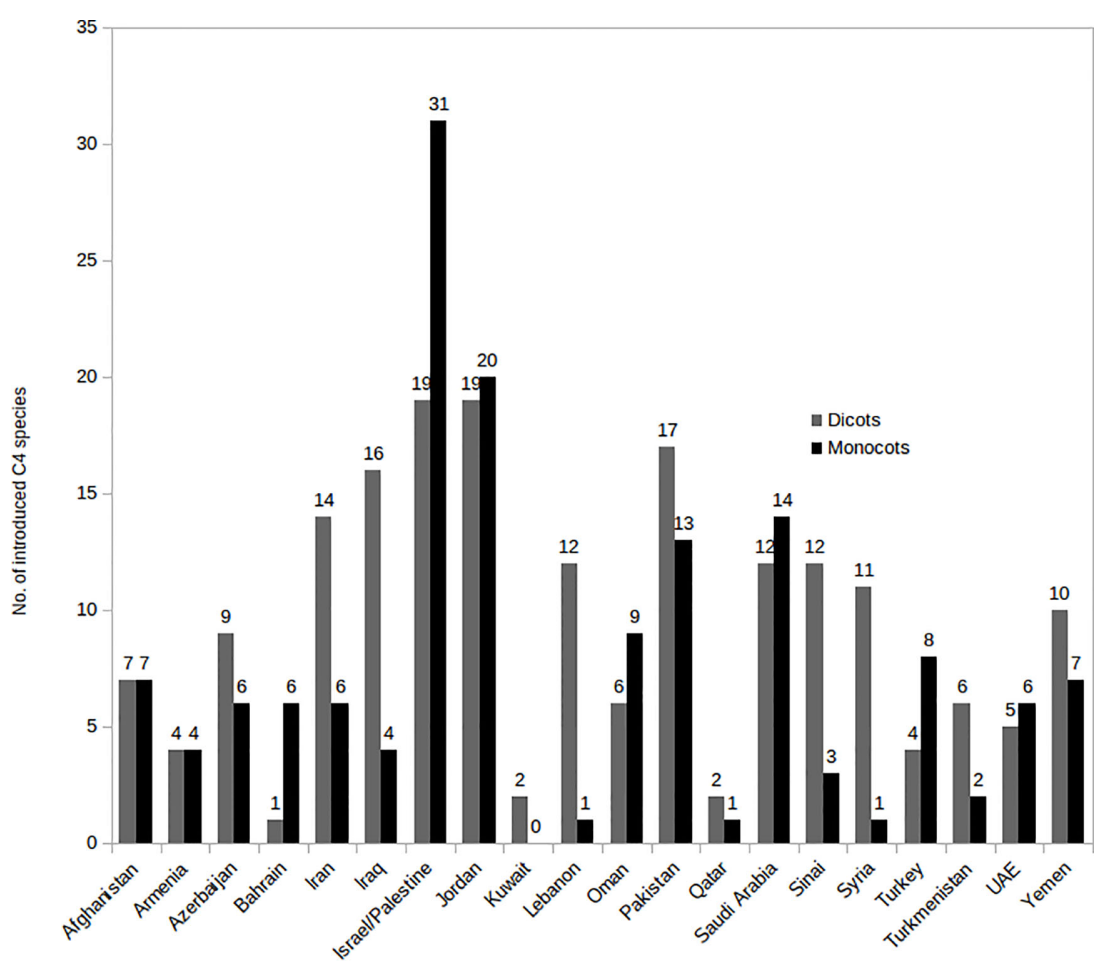

FIGURE 3 | Distribution of introduced $\mathrm{C}_{4}$ Monocots and Eudicots per country in various Southwest (SW) Asian countries.

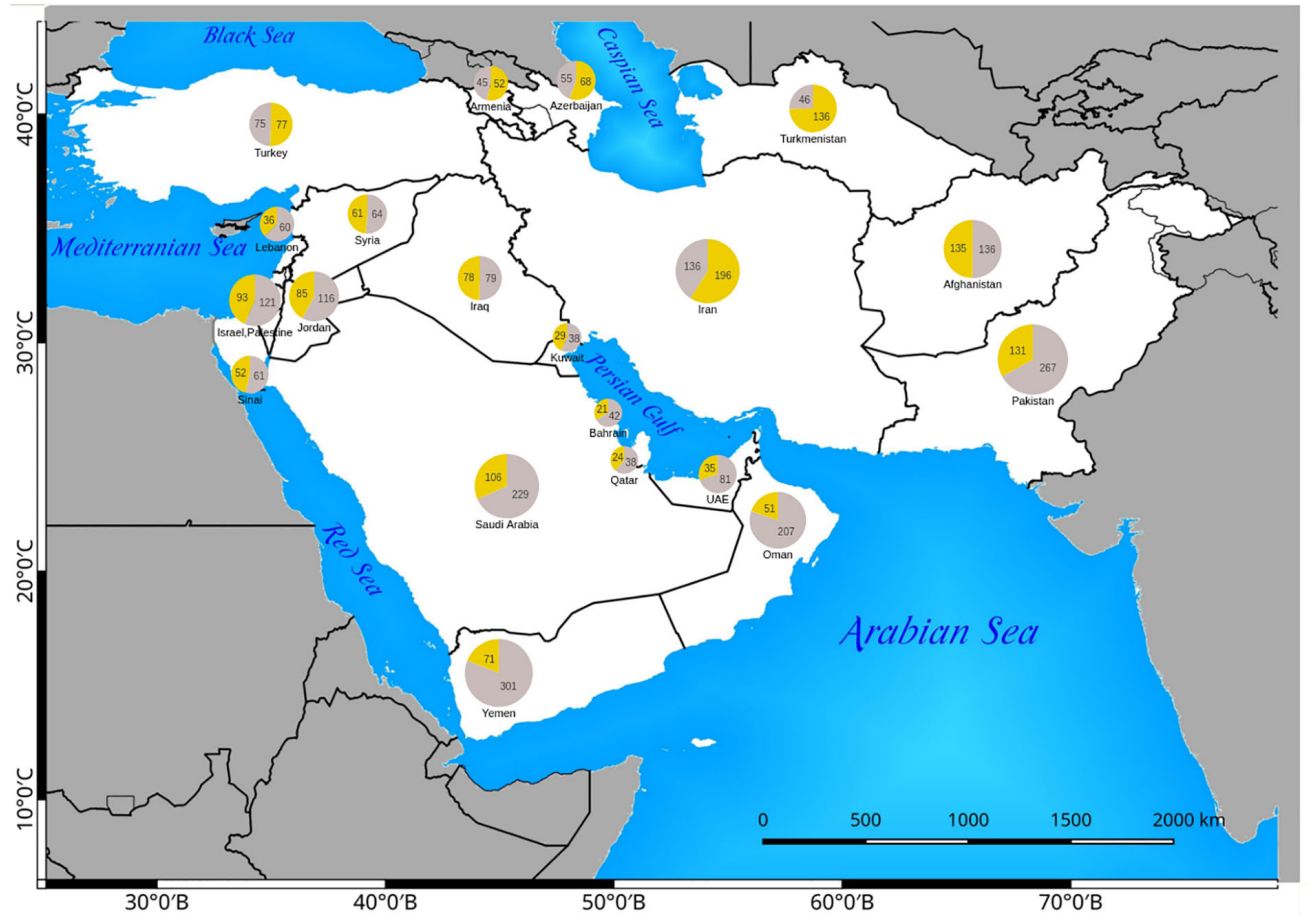

FIGURE 4 | Distribution of native Eudicot (yellow) and Monocot (gray) species in Southwest (SW) Asian countries. The absolute number of $\mathrm{C}_{4}$ Monocots and Eudicots are indicated in the respective pie charts. 
or less equal proportion of Monocot/Eudicots such as Armenia, Azerbaijan, Afghanistan, Turkey, Syria, Iraq, and Sinai Peninsula; 3) counties with higher percentage of $\mathrm{C}_{4}$ Monocots, that is all other countries located in southern parts of the region.

The countries with the highest number of introduced $\mathrm{C}_{4}$ plants are Israel and Palestine with 50 introduced species, Jordan with 39 introduced species, and Pakistan with 30 introduced species respectively. The percentage of $\mathrm{C}_{4}$ plants in relation to total number of recorded plant species per country is highest in Kuwait (23\%), Bahrain (22.5\%), Qatar (22\%), and Oman (20\%), respectively (Figure 5).

\section{$\mathrm{C}_{4}$ Endemics of Southwest Asia}

One hundred forty-one $\mathrm{C}_{4}$ species (36 Monocots and 105 Eudicots, 93 of which are Chenopodiaceae) are endemics of SW Asia; 74 of those (22 Monocots and 52 Eudicots) are strict "country endemics." The highest number of "country endemics" are documented in Iran (27 species), Yemen (14 species, 9 of which are endemic to the island of Socotra), Afghanistan (8 species), and Oman (7 species), respectively. The highest number of endemism occurs in Chenopodiaceae (93 species) and Poaceae (31 species). The three endemic richest genera (with 10 or more endemic species) are Halothamnus (12 endemic sp. in SW Asia), Halimocnemis, and Climacoptera (respectively 10 endemic sp. in SW Asia).

The only generic $\mathrm{C}_{4}$ endemic of the area is the monotypic genus Halarchon (Halarchon vesiculosum) restricted to
Afghanistan. Except a few old records outside of SW Asia, the range of three known species of Bienertia is limited to this area.

\section{Climate Correlation}

The species-richness of $\mathrm{C}_{4}$ Chenopodiaceae increases with increasing continentality and decreases with increasing mean summer precipitation (Figures 6A, E). The $\mathrm{C}_{4}$ richness of Cyperaceae increases with increasing mean annual temperature and is negatively affected by increasing continentality (Figures 6B, G). The number of $\mathrm{C}_{4}$ Poaceae increases with increasing mean annual daily temperature (Figure $\mathbf{6 H}$ ). Totally, the diversity and abundance of $\mathrm{C}_{4}$ plants increases with increasing annual daily temperature and duration of the dry season and decreases with increasing continentality (Figures 6C, F, I). Finally, the prevalence of Monocots over Eudicots is related to increasing average summer precipitation (Figure 6D).

\section{Life Forms and Ecotypes}

Life forms and ecotypes of the $\mathrm{C} 4$ plants are shown in Figures 7A, B.

\section{Phytogeographic Distribution of $\mathrm{C}_{4}$ Species of Southwest Asia}

The phytogeographic distribution of $\mathrm{C}_{4}$ species of SW Asia are shown in Figure 7C.

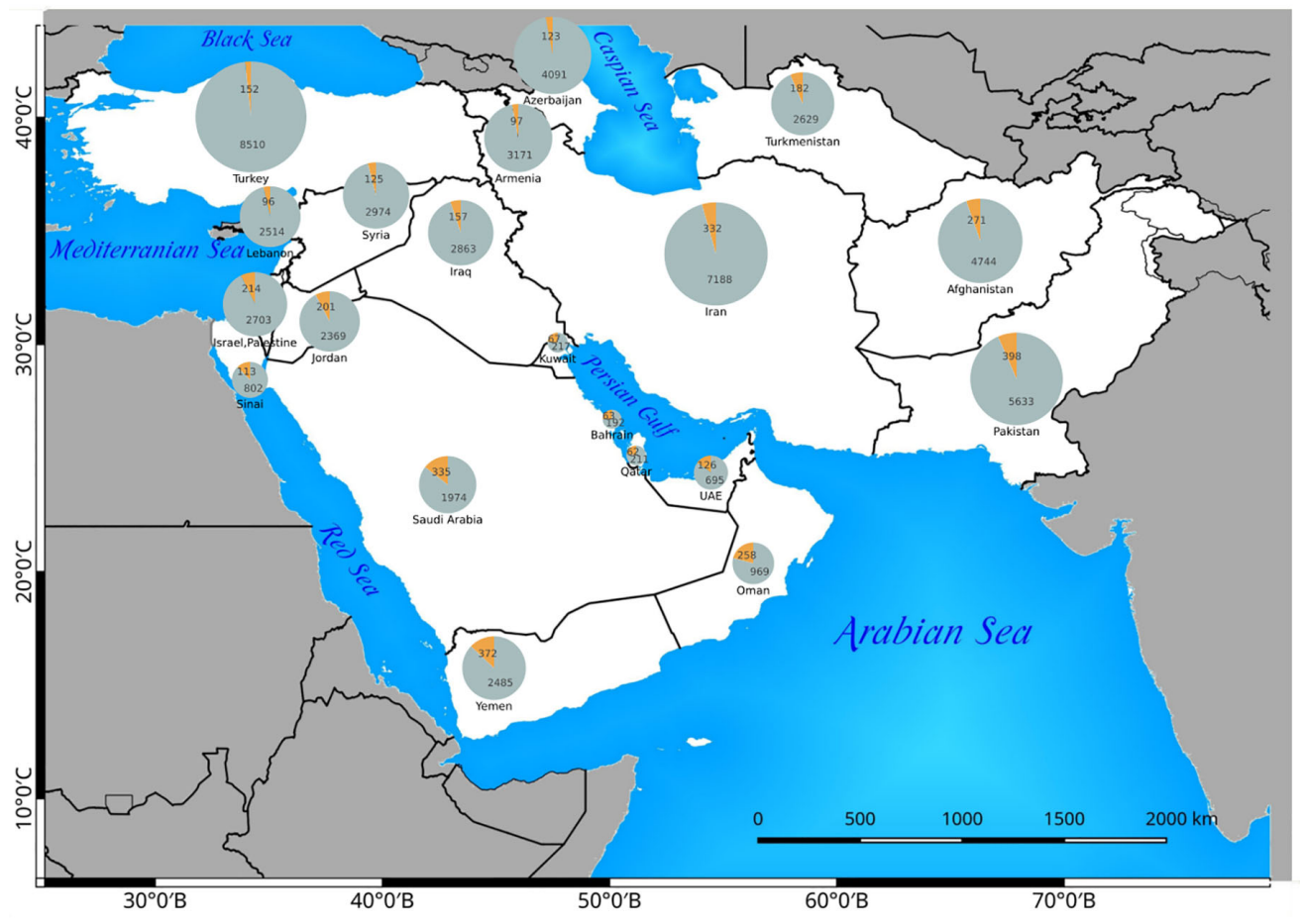

FIGURE 5 | The distribution of $\mathrm{C}_{4}$ plants (orange) in relation to the total flora (gray) of any Southwest (SW) Asian country. The absolute number of $\mathrm{C}_{4}$ and $\mathrm{C}_{3}$ species are indicated in the related pie charts. 
A

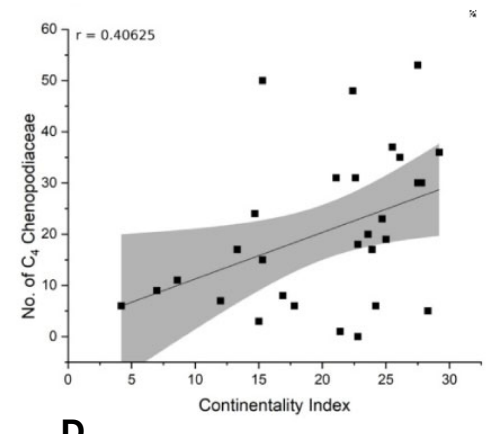

D

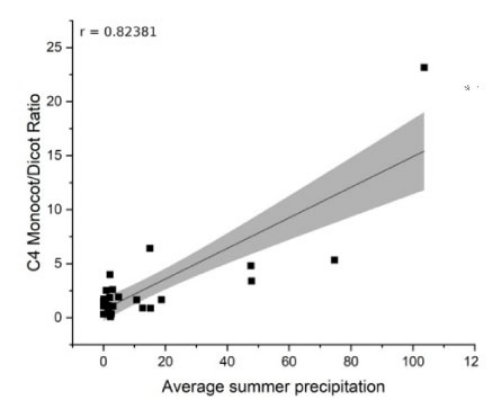

G

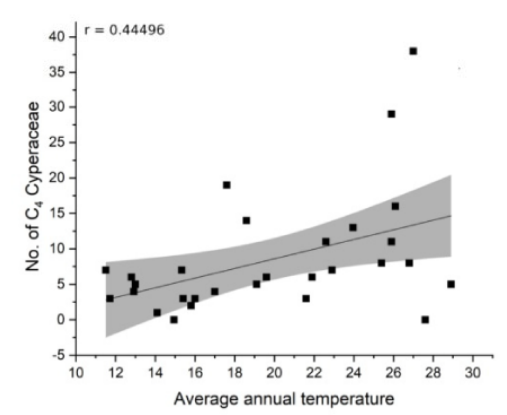

B

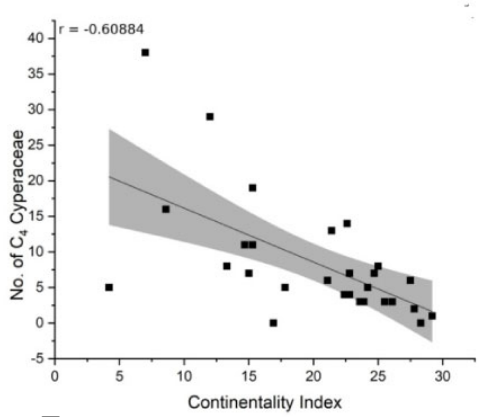

E

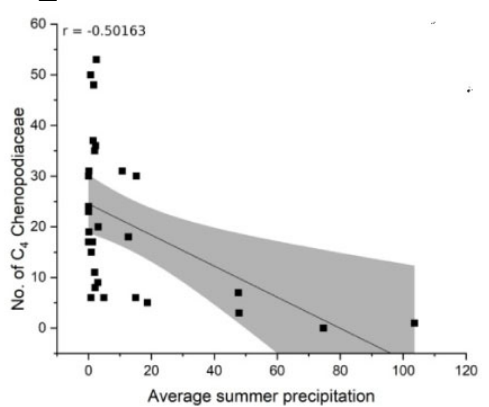

H

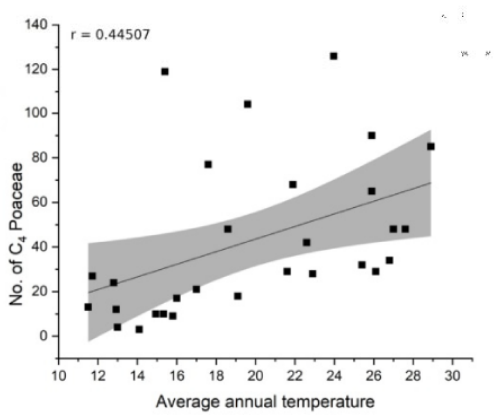

C
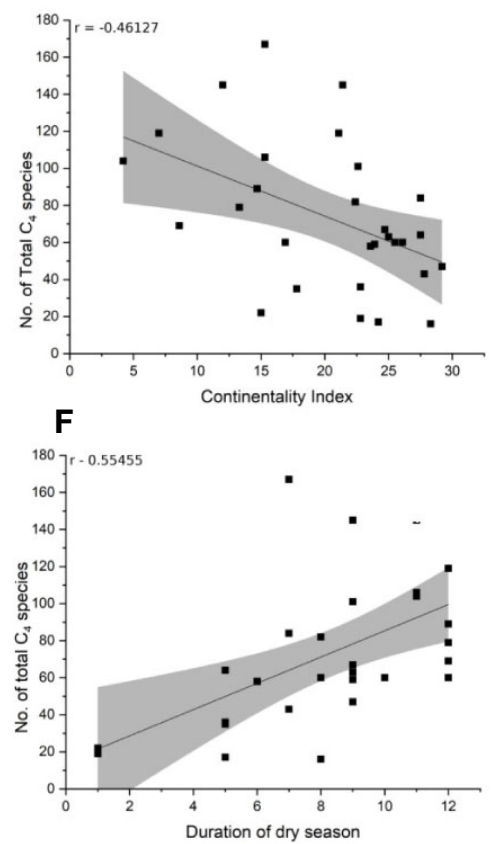

I

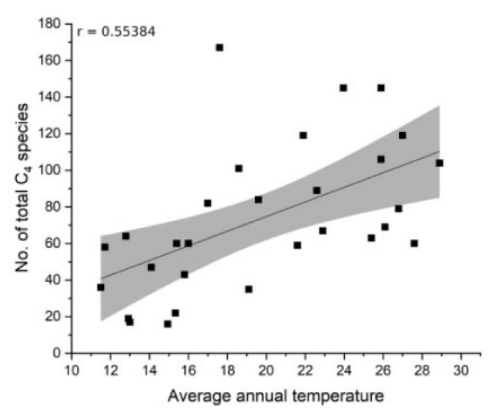

FIGURE 6 | Correlation of climate variables and distribution of $\mathrm{C}_{4}$ main taxonomic groups (Chenopodiaceae, Cyperaceae, Poaceae, Monocot/Eudicot ratio). (A-C) Continentality index. (D, E) Average summer precipitation. (F) Duration of dry season. (G-I) Average annual temperature.

\section{Occurrence of $\mathrm{C}_{4}$ Biochemical Subtypes}

Based on major taxonomic groups $\left(\mathrm{C}_{4}\right.$ Poaceae, $\mathrm{C}_{4}$ Cyperaceae, and $\mathrm{C}_{4}$ Eudicots), the division in metabolic subtypes is as follows. Within the $\mathrm{C}_{4}$ Eudicots NAD-ME metabolic types occur in the Cleome gynandra, Cleome angustifolia, Amaranthus spp., $\mathrm{C}_{4}$ Atriplex, Caroxyleae tribe, Bienertia, Suaeda sect. Salsina, Suaeda sect. Schoeberia, Calligonum, Gisekia, Hypertelis, Blepharis, Anticharis, and Tetraena simplex $\mathrm{C}_{4}$ lineages (ca. 213 species). The NADP-ME subtype occurs in Flaveria clade A, Euploca, $\mathrm{C}_{4}$ Polycarpaea, $\mathrm{C}_{4}$ Aerva, Gomphrena, $\mathrm{C}_{4}$ Althernanthera, $\mathrm{C}_{4}$ Camphorosmeae, $\mathrm{C}_{4}$ Salsoleae, Boerhavia, Euphorbia subgen. Chamaesyce, and Tribulus/Kallstroemia $\mathrm{C}_{4}$ lineages (ca. 167 species). $\mathrm{C}_{4}$ Sesuvioideae and Portulaca include both NADP-ME and NAD-ME metabolic types.

Within Poaceae a NAD-ME subtype (including mixed NADME/PEP-CK subtypes) is present in Centropodia, Melinidinae,
Panicinae, and core Chloroideae (ca. 213 species), while a NADPME subtype (including mixed PEP-CK/NADP-ME subtypes-for further information consult Supplementary Appendix Table 1) is present within Alloteropsis, tribe Andropogoneae, Aristida, tribe Arundinelleae, Tristachyideae, Digitaria, tribe Cenchrinae, Paspalum, and Stipagrostis (228 species). Within the Cyperaceae $\left(\mathrm{C}_{4}\right.$ Cyperus, $\mathrm{C}_{4}$ Fimbristylis, and Bulbostylis $\mathrm{C}_{4}$ lineages, 100 species) and within the Hydrocharitaceae (Hydrilla and Elodea $\mathrm{C}_{4}$ lineages) all species known to perform NADP-ME metabolic type.

\section{Isotope Data}

Two hundred thirty-four $\delta^{13} \mathrm{C}$-isotope ratios, mainly for species with previously unpublished data, are presented in the Supplementary Appendix Table 1 (data marked with ${ }^{*}$ and + ). Additionally, the $\delta^{13} \mathrm{C}$-isotope ratios of the $\mathrm{C}_{3}$ plants Polycarpaea caespitosa Balf., Polycarpaea spicata Wight ex Arn., Polycarpaea repens (Forsskal) 
A

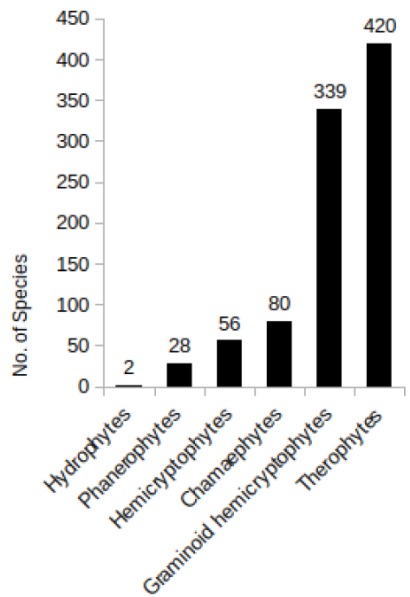

B

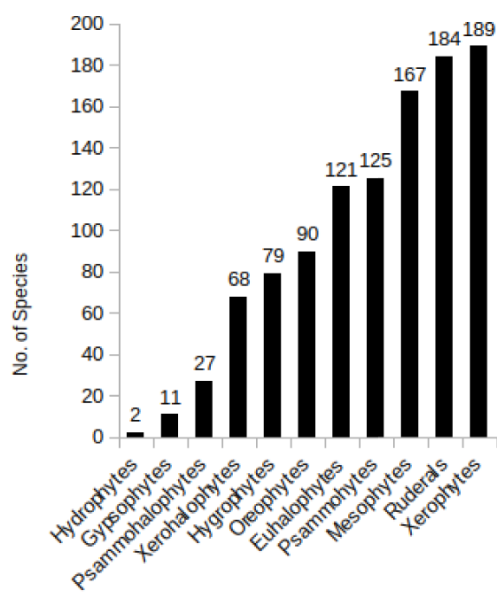

C

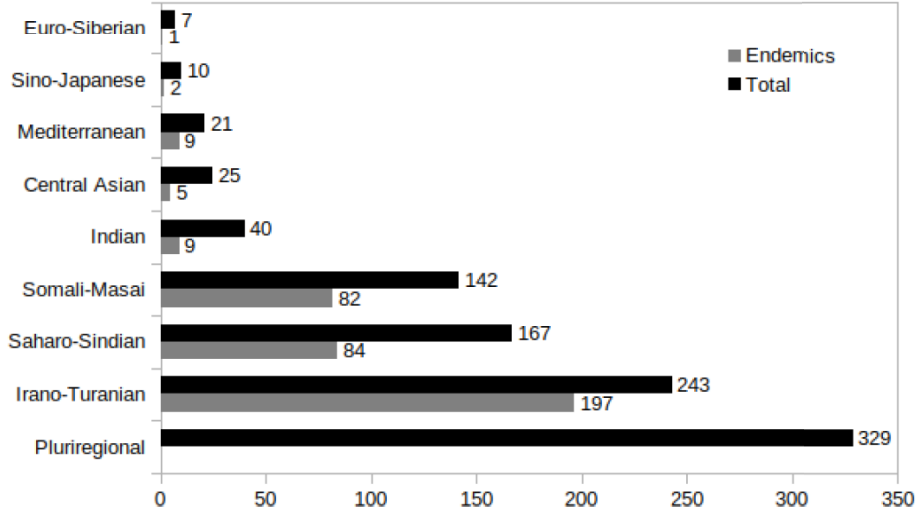

FIGURE 7 | (A-C) $\mathrm{C}_{4}$ Species distribution in different growth types (A), predominant ecotypes (B), and different phytogeographic regions in Southwest (SW) $\mathrm{C}_{4}$ plants. A plant was considered as pluriregional, when occur in more than three phytochorion, and as endemic, when present in just one phytochorion.

Aschers. and Schweinf., Cyperus pulcherrimus Willd. ex Kunth, and Fimbristylis turkestanica (Regel) B. Fedtsch., distributed in Southwest Asia, are published in Supplementary Table 3.

\section{DISCUSSION}

\section{Southwest Asia Center of Origin of Major $\mathrm{C}_{4}$ Flora}

The checklist appended in this paper has been compiled with great caution to include as much data as available, thanks to intensive Flora compilation in SW Asian countries published during more than half a century (Rechinger, 1963-2015; Davis, 1966-2001; Guest and Ghazanfar, 1966-2013; Nasir and Ali, 1970-2003; Nikitin and Geldikhanov, 1988; Miller and Cope, 1996) and intensive botanical explorations in the region. However, as a first contribution, it requires more data to fill some gaps on local flora of the Levant (Syria, Jordan and
Lebanon) and the absence of up-to-date information on specific groups such as Cyperaceae in the Arabian Peninsula.

In spite of our efforts to check photosynthetic types of all putative $\mathrm{C}_{4}$ groups, we could not get enough samples for a few Polycarpaea species. The preliminary phylogenetic studies show that Polycarpaea is polyphyletic including both $\mathrm{C}_{3}$ and $\mathrm{C}_{4}$ species. It has been suggested to segregate $C_{4}$ species in a separate genus Polia (Kool, 2012). Within our area, however, only Polycarpaea corymbosa (L.) Lam. is a reliable $\mathrm{C}_{4}$ species. Some other SW Asian species such as $P$. repens (Forsskal) Aschers. and Schweinf., P. spicata Wight ex Arn., P. hassalensis Chamberlain, and P. haufensis A.G. Miller) have been reported to be $\mathrm{C}_{3}$ according to Kool (2012) and a few ones (Supplementary Table 3) require further investigation.

So far 174 species of Calligonum have been described worldwide (Soskov, 2011), however phylogenetic studies and attempts to barcode these species revealed little information to support this diversity (Tavakkoli et al., 2010; Li et al., 2014; Doostmohammadi et al., 2020). We followed the recent 
monography of the genus which accepts a wide species concept including only 28 species and 8 interspecific hybrids (Soskov, 2011) and recent minor changes by Shi et al. (2016).

The polymorphic, mainly Saharo-Sindian genus Tribulus, has been partly reviewed for India and Saudi Arabia by synonymizing many species (Al-Hemaid and Thomas, 1996; Varghese et al., 2006). A systematic review of the genus in our area is highly welcome.

Despite recent progress in the taxonomy and phylogeny of Chenopodiaceae (Kadereit et al., 2003; Akhani et al., 2007), still there are ambiguities in monophyly of some genera such as Hammada. The phylogenetic tree based on combined nuclear and chloroplast markers showed polyphyly of three species Hammada articulata, $H$. salicornica, and $H$. griffithii (Akhani et al., 2007; Schüssler et al., 2017). In a long debate on the nomenclatural status of the Kali-clade within Salsoleae which has been separated from Salsola s.l. based on strong molecular and morphological data, recent unexpected decision on replacing the type of the genus Salsola by Salsola kali L. instead of S. soda by International Code of Nomenclature (Akhani et al., 2014; Mosyakin et al., 2017; Turland et al., 2018) resulted in instability and chaos of all names used since 2007. Therefore, in order to keep phylogenetic classification of Salsoloideae we are pushed to change the name of many species traditionally classified in Salsola into Soda (see Nomenclatural Appendix). Furthermore, we provide new combinations for some species which have been overlooked in the phylogenetically based system of Salsoleae by Akhani et al. (2007).

The phylogenetic relationships within Poaceae have seen several recent revisions (Hodkinson et al., 2002; Kellogg, 2015; Soreng et al., 2015; Soreng et al., 2017). These revisions regarded also changes within the PACMAD clade (Panicoideae, Arundinoideae, Chloridoideae, Micrairoideae, Aristidoideae, and Danthonioideae subfamiles), which includes all $\mathrm{C}_{4}$ Poaceae lineages. While some phylogenetic relationships may need further clarification (e.g., genera Saccharum, Miscanthus, Miscanthidium, etc.), several clades have been synonymized [e.g., Urochloa (=Brachiaria, Snowdenia)] or separated (e.g., Narenga separated from Saccharum). In the nomenclatural appendix we provide new combinations for the species that have been affected by the last revision by Soreng et al. (2017).

Based on our data (Table 1), the $\mathrm{C}_{4}$ flora of SW Asia includes 923 (ca. 11\% of world known $\mathrm{C}_{4}$ species) and represent 48 of 65 known $\mathrm{C}_{4}$ lineages of the world (Sage, 2016; Akhani et al., 2007; Kadereit and Freitag, 2011). The area, as one of the major center of diversity of $\mathrm{C}_{4}$ Eudicots, harbors the origin of ca. $19 \mathrm{C}_{4}$ Eudicot lineages and has representatives of all families known to have $\mathrm{C}_{4}$ species either as native or introduced (Sage, 2016) (Table 1, Supplementary Appendix Table 1).

SW and Central Asia which represent largely the Irano-Turanian flora are the center of origin of at least $12 \mathrm{C}_{4}$ Chenopodiaceae lineages (Akhani et al., 2007; Sage, 2011; Sage, 2016). We consider Salsoleae s. str. as one $\mathrm{C}_{4}$ origin with understanding that present topologies suggest two additional origins that are not well resolved (Akhani et al., 2007; Kadereit and Freitag, 2011).

The region shows also the highest diversity of species, anatomical and ecological types, and life forms in $\mathrm{C}_{4}$ Eudicots (see
Supplementary Appendix Table 1). Of those lineages, 11 (Suaeda sect. Salsina, Suaeda sect. Schoberia, Bienertia, Camphorosma, Bassia, $\mathrm{C}_{4}$ Salsoleae s. str., Caroxyleae, Salsola (=Kali), Nanophyton, $\mathrm{C}_{4}$ Atriplex, and $\mathrm{C}_{4}$ Tecticornia) are distributed throughout SW Asia. The origin of the strictly psammophytic genus Calligonum (Polygonaceae) has been proposed to be in northern Iran (IranoTuranian region), on the former shores of the Tethys sea, from where it spread to Central, South, and Southwest Asia and northern Africa (Soskov, 2011). On the other hand, $\mathrm{C}_{4}$ Aizoaceae, $\mathrm{C}_{4}$ Zygophyllaceae (Tetraena simplex and Tribulus/Kallstroemia lineages), the Cleome angustifolia, and $\mathrm{C}_{4}$ Aerva lineages and probably $\mathrm{C}_{4}$ Gisekia and $\mathrm{C}_{4}$ Polycarpaea have originated on the Arabian Peninsula and adjacent Africa (Sage, 2011).

\section{$\mathrm{C}_{4}$ Dominated Vegetation in Southwest Asia}

$\mathrm{C}_{4}$ dominated plant communities in SW Asia occur in a wide range of habitats:

1) Psammophytic $C_{4}$ vegetation occurs in inland sandy deserts and coastal dunes in the following types of vegetation: a) The large sand deserts of the Irano-Turanian and Saharo-Sindian vegetation in Iran, Turkmenistan, Afghanistan, Iraq, and the Arabian Peninsula. The Irano-Turanian sandy deserts are mainly dominated by pure or mixed communities of highly specialized psammophytic $\mathrm{C}_{4}$ Eudicots [(Calligonum spp. (Figures 8J, 9E)], Haloxylon spp., Xylosalsola spp.)] and Monocots (Stipagrostis spp.) (Nechayeva, 1992; Ghasemkhani et al., 2008; Fayvush and Aleksanyan, 2016). In the deserts of Turkmenistan and Central Iran Haloxylon communities may be rather densely populated, forming "Saxaul forests" (Figure 8K). From central Iran toward the Levant and the Rub Al-Khali the dominating $\mathrm{C}_{4}$ Eudicots change [(Calligonum spp., Hammada salicornica (Figure 8I), Cornulaca spp., Anabasis articulata)] while the diversity of psammophytic $\mathrm{C}_{4}$ Monocot communities increases [Cyperus spp. (Figure 9A), Stipagrostis spp. (Figure 9E), Aristida spp., Centropodia spp. (Figure 9D), Panicum spp.] (Ghazanfar and Fisher, 1998), similarly the sand dune vegetation in Lut desert in SE Iran and the deserts of South-East Pakistan are dominated by communities of Calligonum polygonoides, Calligonum mongolicum, Soda stocksii (Salsola stocksii), Tribulus spp. (Figure 10H), Aerva javanica, Lasiurus scindicus and Cymbopogon jwarancusa, Stipagrostis multinerva, Desmostachya bipinnata (Dasti and Agnew, 1994). b) Hamadas, gravel, and coarse sand deserts show rather sparse vegetation, sometimes dominated by sparse communities of chenopods like Hammada salicornica (Figure 8I), Cornulaca monacantha, and Anabasis spp. in the tropical deserts of the South SW Asia (Ghazanfar and Fisher, 1998; Akhani, 2015a). However, the temperate deserts of Iran are covered by dense or sparse grasslands of Stipagrostis plumosa, often mixed with Artemisia subshrubs. c) Coastal dune vegetation varies within the region. E.g., the sandy dunes of the Indus delta and Pakistani Balochistan present mixed 


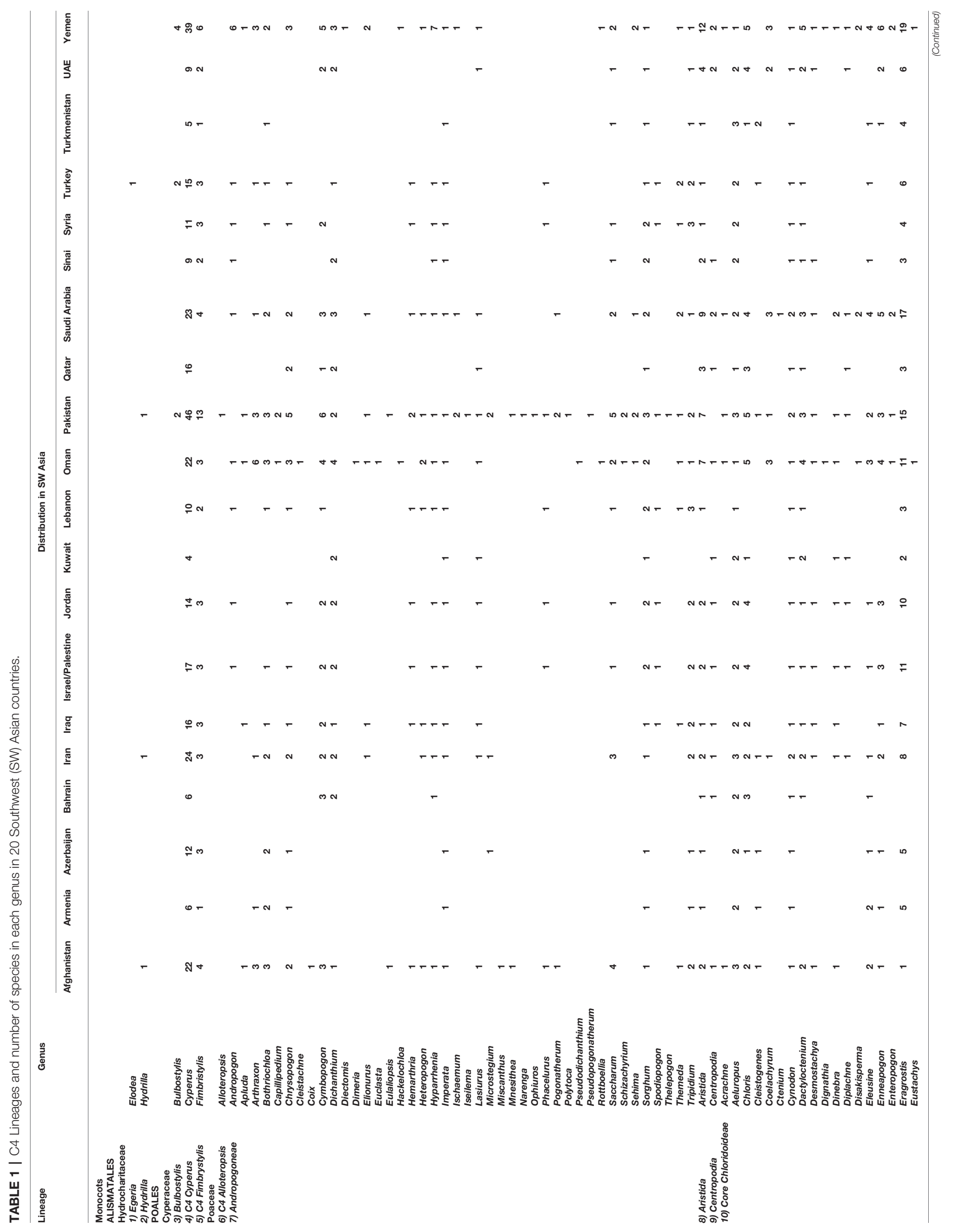




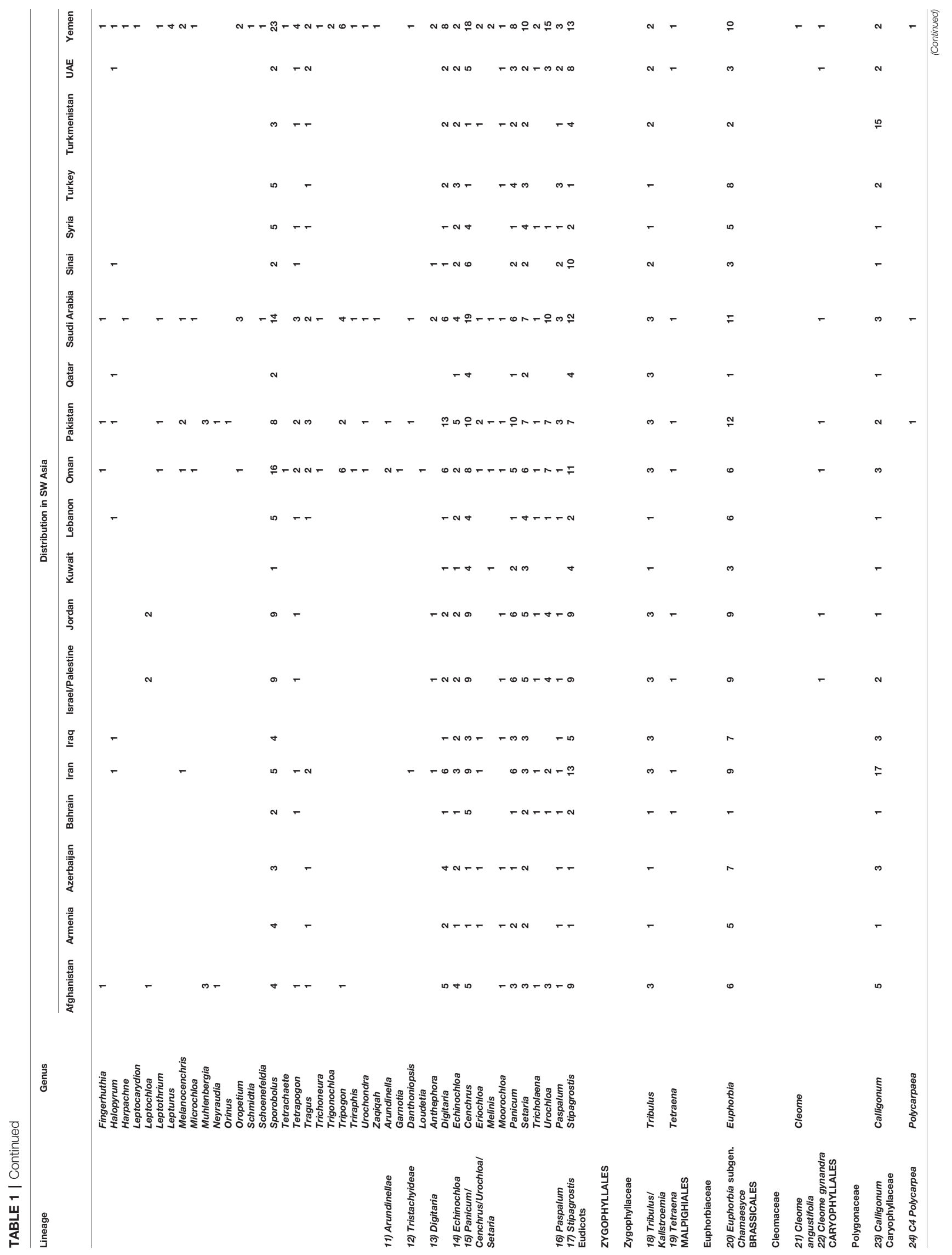




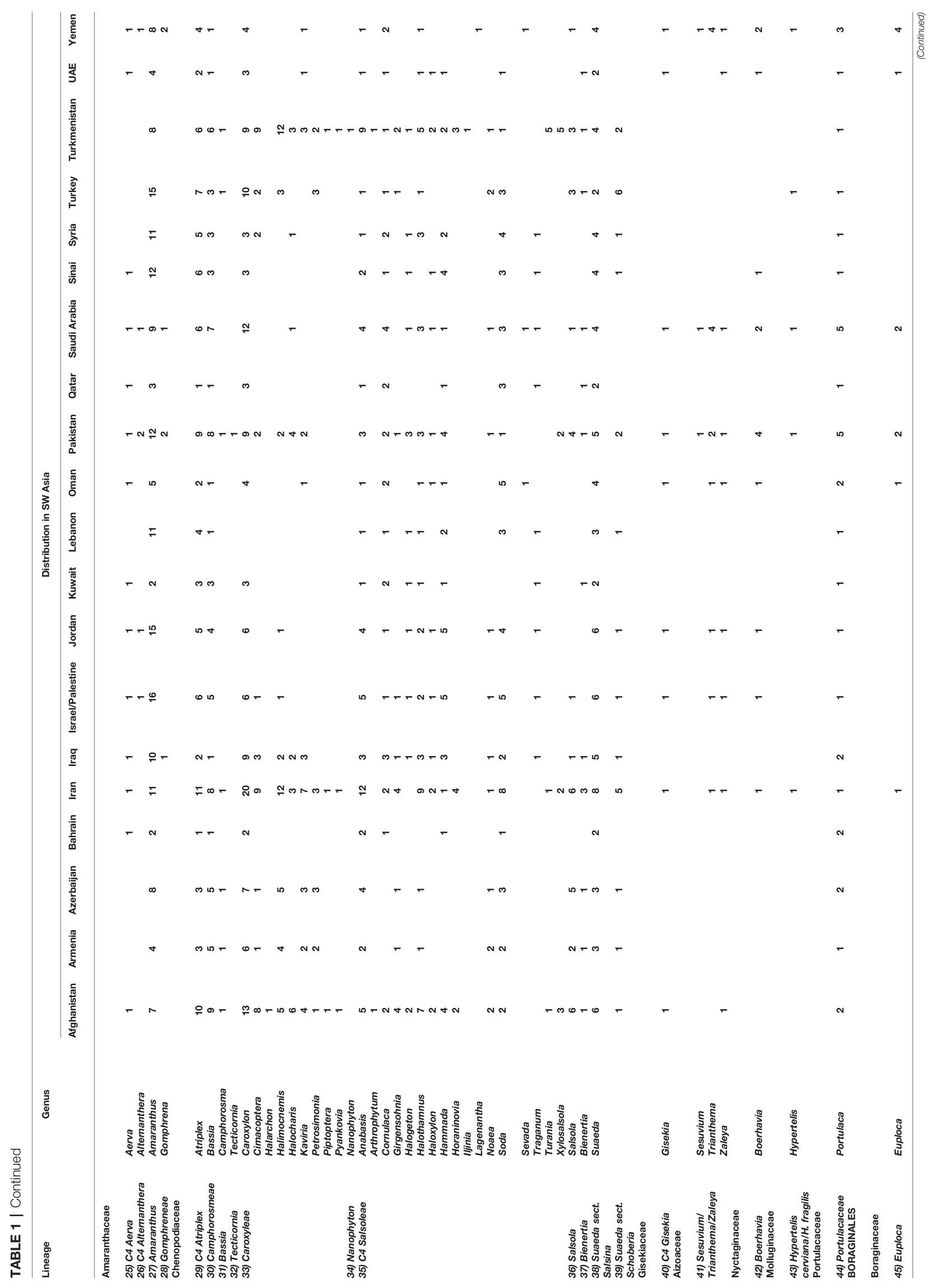




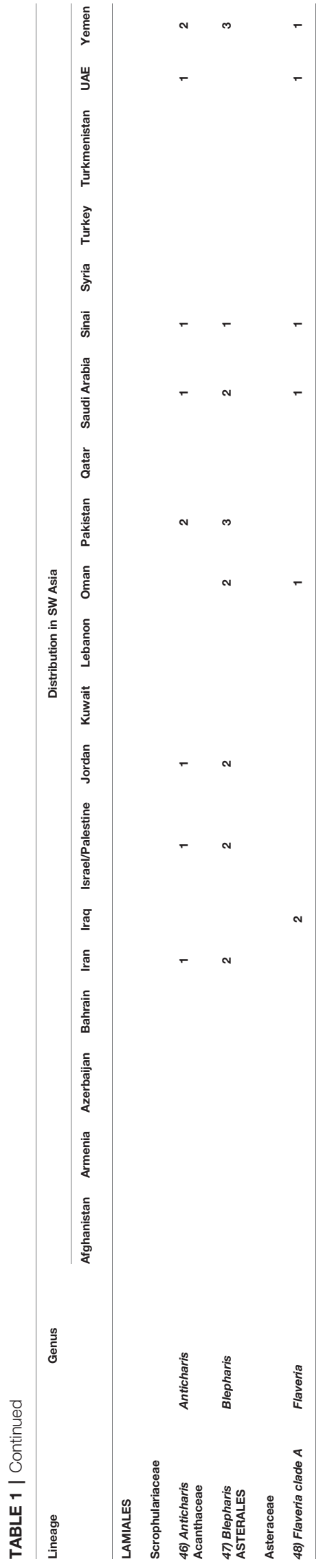

psammophytic communities with frequent presence of Aerva javanica (Figure 10D), Cyperus arenarius, Soda stocksii (Salsola stocksii), Hammada salicornica, and Cenchrus biflorus (Snead and Tasnif, 1966; Ananda Rao and Meher-Homji, 1985). The coastal dunes of the Arabian Peninsula are dominated by communities of halophytic sand grasses and sedges like Zaqiqah mucronata, Urochondra setulosa, Sporobolus spp., Dactyloctenium spp., Leptothrium senegalense, Halopyrum mucronatum, Cenchrus divisus, Panicum turgidum, Lasiurus scindicus, Coelachyrum piercei, and Cyperus spp. as well as Chenopods like Cornulaca monacantha and Atriplex stocksii (Ghazanfar and Fisher, 1998; Brown and Mies, 2012).

2) Halophytic $C_{4}$ vegetation is highly diverse and affected by topography, water level, and local land use. Saline habitats range from marly and clayey hills with varying salt and gypsum composition to inland dry saline plains with clay, silt, and sandy soils in sabkhas, saline wetlands, and lakes, as well as coastal sabkhas and shorelines. They composed a wide range of communities from pure $\mathrm{C}_{4}$ communities to $\mathrm{C}_{4}$ patches occurring in microhabitats of $\mathrm{C}_{3}$ dominated communities:

a) Dry marly or clayey hills with varying salt and gypsum composition are often dominated by xerohalophytic and gypsophytic $\mathrm{C}_{4}$ Chenopods. In Iran such habitats are sparsely vegetated by xerohalophytic and gypsohalophytic shrubs like Anabasis eugeniae (Figure 8F), Anabasis calcarea, Anabasis firouzii (Figure 10B), Halothamnus auriculus, Halothamnus lancifolius, Xylosalsola arbuscula, Noaea mucronata, Caroxylon verrucosum, Suaeda dendroides, Kaviria tomentosa, K. aucheri, and K. zedzadii (Akhani, 2006; Pérez-García et al., 2018). In Israel similar saline chalk and marl slopes are dominated by communities of Suaeda asphaltica, Hammada negevensis, and Caroxylon tetrandrum (Danin and Orshan, 1999).

b) Saline plains, salt marshes, and depressions with varying water-table offer a habitat to pure or mixed $\mathrm{C}_{4}$ Chenopod communities, that are typical for the Irano-Turanian and Saharo-Sindian regions. Such communities are divided into two main subgroups namely "the $\mathrm{C}_{4}$ dominated shrubby communities (vegetation class Haloxylo-Kavirietea tomentosae)" and "the $\mathrm{C}_{4}$ rich Irano-Turanian nitrophilous annual halophytic communities (vegetation class CaroxyloClimacopteretea)." The $\mathrm{C}_{4}$ shrubby dominated communities are composed of Haloxylon ammodendron, Kaviria tomentosa, Hammada spp., Halothamnus subaphyllus, $H$. glaucus, Soda rosmarinus (Seidlitzia rosmarinus), Cornulaca monacantha, Anabasis aphylla, A. haussknechtii, A. iranica spp., and Suaeda fruticosa (Akhani, 2004). The $\mathrm{C}_{4}$ rich IranoTuranian nitrophilous annual halophytic communities composed of a rich variety of annual chenopods like Climacoptera spp. (Figures 8G and 10I), annual Caroxylon spp., Halimocnemis spp., Petrosimonia spp., Cornulaca aucheri, annual Atriplex spp., Halocharis spp., Pyankovia brachiata, Bienertia spp. (Figures 8G and 10J), annual Suaeda spp. (S. cochlearifolia, S. gracilis, S. microsperma, S. khalijefarsica, S. arcuata, S. aegyptiaca, S. altissima), Bassia 

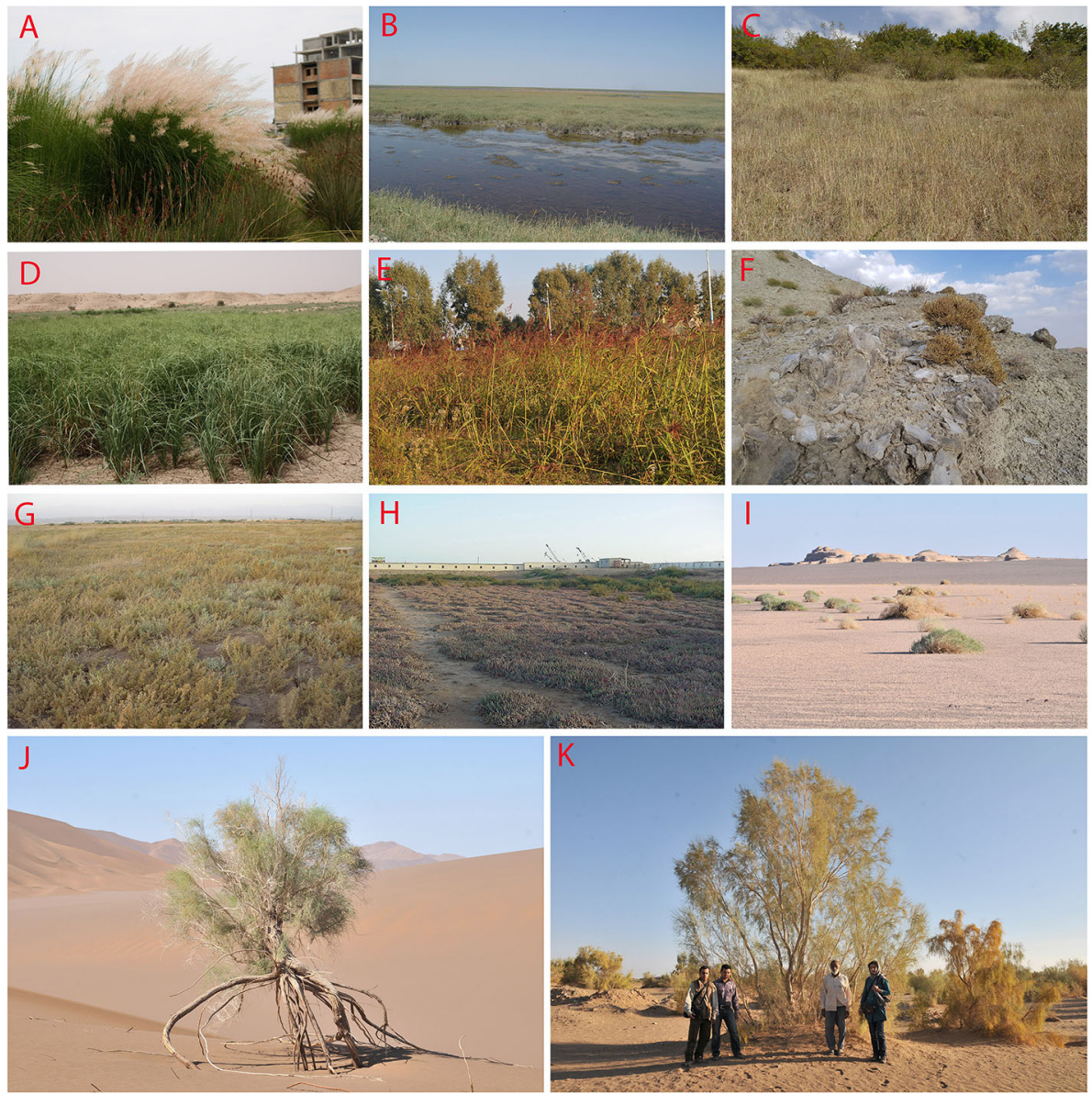

FIGURE 8 | (A-K) Habitats dominated by $\mathrm{C}_{4}$ vegetation: (A) habitat with high water table in Northeast (NE) Iran, near Caspian Sea, dominated by Saccharum spontaneum L. (B) euhalophytic vegetation of Aeluropus litoralis (Gouan) Parl. community, close to the SE Caspian shores, Turkman Sahra salt flats, Iran; (C) $\mathrm{C}_{4}$ grassland in a temperate forest on rocky S-facing slopes of Golestan National Park, Iran; (D) Desmostachya bipinnata on temporarily flooded dry soils in Khuzestan, Southwest (SW) Iran; (E) ruderal vegetation dominated by Sorghum halepense (L.) Pers., SE Caspian coasts, Farahabad, Mazandaran, Iran; (F) gyspsiferous outcrop of Anabasis eugeniae lljin and Anabasis calcarea (Charif \& Aellen) Bokhari \& Wendelbo community, NW Iran; (G) euhalophytic community in central Iran, 60 km W Tehran mainly dominated by Bienertia cycloptera Bunge ex Boiss. and Climacoptera turcomanica (Litv.) Botsch. (H) shores of the Makran coast (Pakistan) dominated by Tecticornia indica (Willd.) K. A. Sheph. \& Paul G. Wilson, (I) Hammada salicornica (Moq.) Iljin community in Desert Lut, S. Iran; (J) Calligonum amoenum Rech. f. on moving dunes in Lut desert; (K) Haloxylon persicum Bunge shrubland near Mesr Village, C. 40 km E of Jandagh, Dasht-e-Kavir, Iran. All photos H. Akhani.

spp. (B. hyssopifolia, B. erinatha, B. eriophora) (Figure 10A), and Soda florida (Seidlitzia florida). (Ghazanfar and Fisher, 1998; Akhani, 2004; Akhani, 2006). This vegetation type develops on disturbed nitrified soils on salinized wastelands, ruderal habitats around the roads, and human settlements and as pioneer communities on exposed high saline soils of dried up salt lakes (Ghorbanalizadeh et al., 2020).

c) The vegetation of coastal saline flats resembles their inland counterparts. Such vegetation is present on the SE shores of the Caspian sea, along the coasts of the Persian Gulf, the Indian Ocean, and in lesser extent along the Red Sea. E.g., the coastal sabkha vegetation of the Persian Gulf is dominated by Suaeda fruticosa, Caroxylon imbricatum, Atriplex leucoclada, Climacoptera sp., Soda rosmarinus (Salsola rosmarinus), and Bienertia sinuspersici, while the Red Sea and Indian Ocean coastal flats harbor communities of Suaeda monoica (Figure 10C), S. moschata, S. vermiculata/S. fruticosa, Atriplex leucoclada, and A. coriacea (Ghazanfar and Fisher, 1998; Akhani and Deil, 2012; Akhani, 2015a). Similar communities occur along the Makran coast and in the saline flats of the Indus delta, these communities also include Suaeda baluchestanica, Halopyrum mucronatum, and the remarkable tropical Tecticornia indica (Figure $\mathbf{8 H}$ ) (Snead and Tasnif, 1966; Voznesenskaya et al., 2008).

d) A remarkable type of $\mathrm{C}_{4}$ halophytic vegetation are $\mathrm{C}_{4}$-grass communities present on saline clayey soils with high watertable, formed by halophytic grasses of the genus Aeluropus (Figure 8B). Such communities occur e.g., on the eastern shores of the Caspian Sea, where Aeluropus littoralis forms almost pure communities on flooded plains in Iran and 

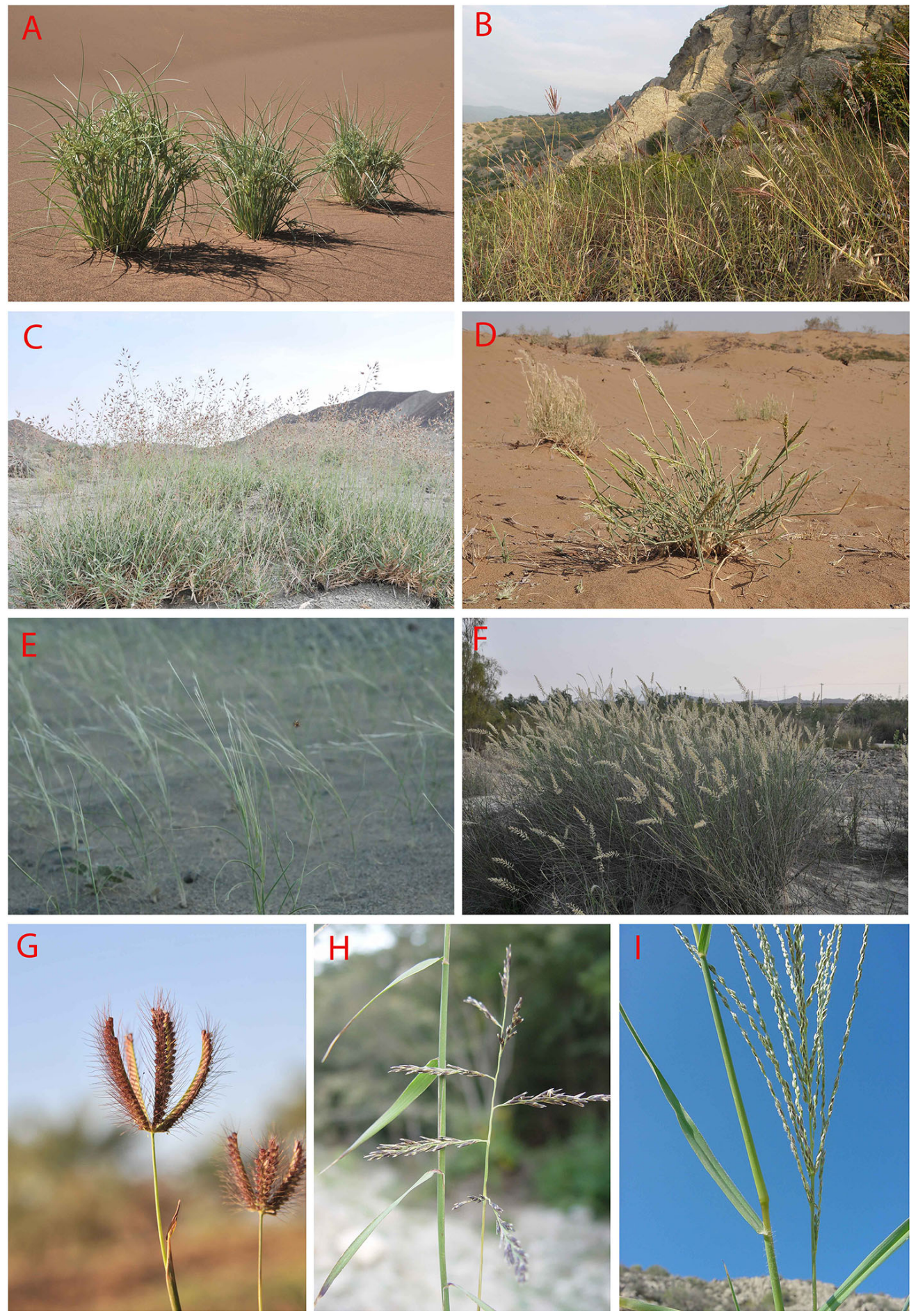

FIGURE 9 | (A-I): Some representatives of important $C_{4}$ Monocot lineages in Southwest (SW) Asia: (A) Cyperus aucheri Jaub. and Spach, sand dune in Desert Lut, Iran; (B) Bothriochloa ischaemum (L.) Keng-B. bladhii (Retz.) S.T. Blake-Cleistogenes serotina (L.) Keng community, S-facing rocky outcrop in Golestan National Park, Iran; (C) Danthoniopsis stocksii (Boiss.) C.E. Hubb., dry river bed, Baluchistan, Iran; (D) Centropodia forskalii (Vahl) Cope, Aran-Bidgol dunes in Esfahan Province, Iran, 6.6.2010; (E) Stipagrostis multinervis H. Scholz, Desert Lut, Iran, 1.4.2011; (F) Cenchrus divisus (J.F. Gmel.) Verloove, 19.2.2013, river side in Bahukalat, Baluchestan, Iran; (G) Chloris barbata Sw., 17.2.2013, ruderal places, in Zehkalut, Kerman, Iran; (H) Cleistogenes serorina (L.) Keng, 13.10.2003, limestone rocky outcrops in Golestan National Park, Iran; (I) Digitaria nodosa Parl., 18.12.2001, rocky shrubland, Kuhe Geno, Hormozgan, Iran (photos by H. Akhani). 

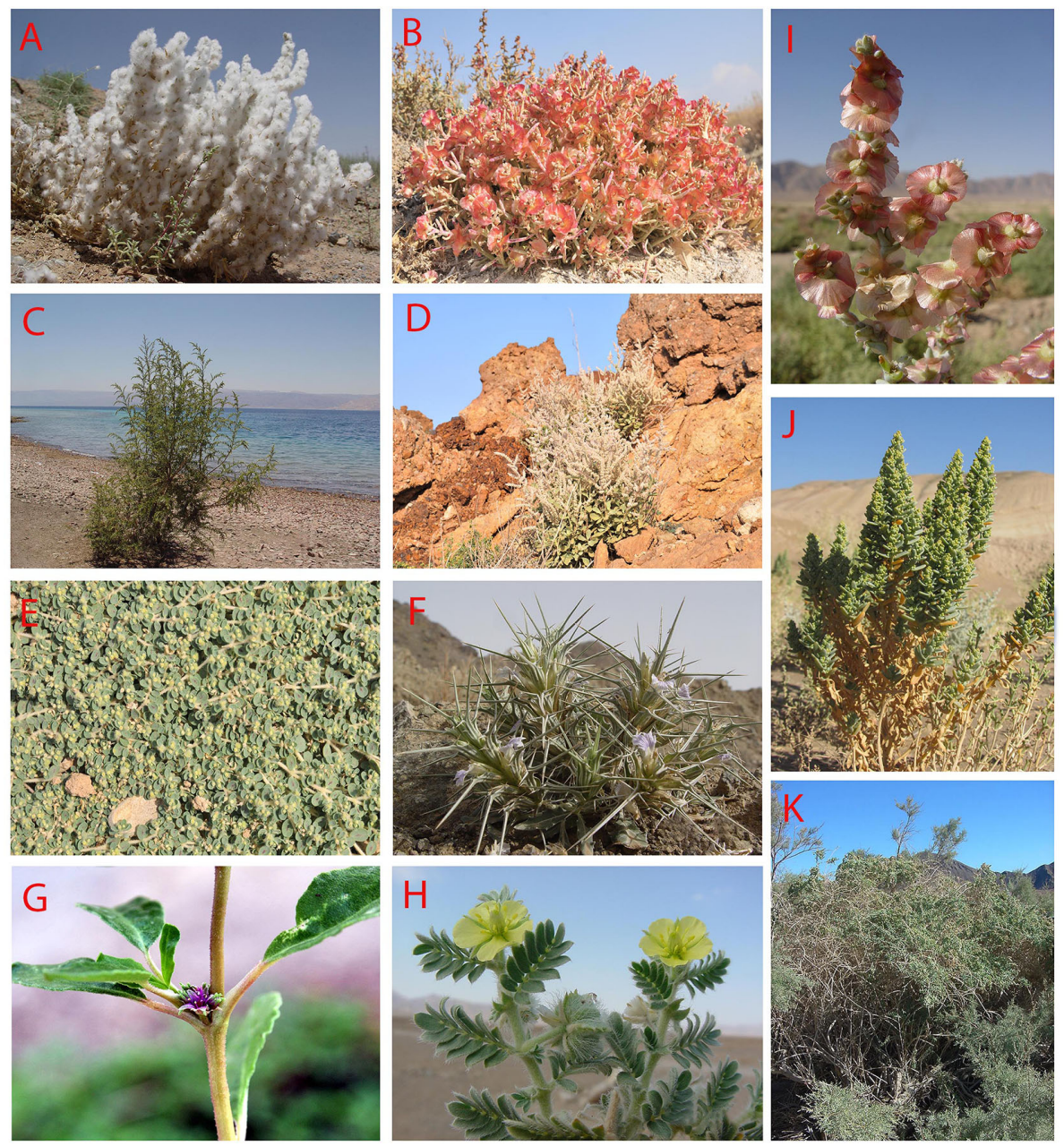

FIGURE 10 | (A-K): Some representatives of important $\mathrm{C}_{4}$ Eudicot lineages in Southwest (SW) Asia: (A) Bassia eriantha (Fisch. and C.A. Mey.) Kuntze, 10.6.2004, Artemisia+Stipagrostis semi-desert steppe, 50 km SE Esfahan, Iran; (B) Anabasis firouzii Akhani, 10.10.2012, marl slopes, Qorkhod Protected Area, N. Khorassan, Iran; (C) Suaeda monoica Forssk. ex J.F. Gmel. 18.6.2007, Red Sea coasts, Aqabeh, Jordan; (D) Aerva javanica (Burm.f.) Juss. ex Schult. 22.2.2013, rocky slopes, Hormoz Island, Persian Gulf; (E) Euphorbia serpens Kunth, 3.7.2014, ruderal soil, Khuzestan, Iran; (F) Blepharis ciliaris (L.) B.L. Burtt, 22.2.2013, gravely-sandy soils, Hormoz Island, Persian Gulf; (G) Trianthema portulacastrum L., 23.2.2013, ruderal places, Hormoz Island, Persian Gulf; (H) Tribulus macropterus Boiss. 18.9.2001, Khuzestan, Iran; (I) Climacoptera chorassanica Pratov, 1.9.2003, hypersaline soils, 40 km SE Birjand, Khorassan, Iran; (J) Bienertia kavirense Akhani, 5.8.2016, Esfahan/Semnan, Iran; (K) Caroxylon abarghuense (Assadi) Akhani and Roalson, 5.10.2001, Touran protected Area, Iran (photos by H. Akhani).

Turkmenistan (Nechayeva, 1992; Rukhlenko, 2001). Similar pure stands and mixed communities of Aeluropus lagopoides with Tamarix spp., Desmostachya bipinnata, and Salvadora oleoides have been reported from inland Sabkhas and salt pans of Iran, Syria, the Arabian Peninsula, and Pakistan (Dasti and Agnew, 1994; Ghazanfar and Fisher, 1998; Akhani, 2006; Al-Oudat and Qadir, 2011). Finally, Aeluropus spp. pure and mixed communities (in association with Suaeda monoica, Fimbristylis spp., etc.) as well as communities of other halophytic grasses, like Sporobolus spp. and Halopyrum mucronatum are also frequent on the shores of the Indian Ocean and the Persian Gulf (Snead and Tasnif, 1966; Ananda Rao and Meher-Homji, 1985; Ghazanfar and Fisher, 1998; Akhani, 2015a).
3) $\mathrm{C}_{4}$ grassland vegetation is limited by high temperatures and the availability of water in the form of summer precipitation or high underground water table (Ghazanfar and Fisher, 1998). The following types of $C_{4}$ grassland communities have been so far described:

a) Oreophytic grasslands on the rocky highlands of $S$ Arabia and Socotra may be distinguished by pure $\mathrm{C}_{4}$ or mixed $\mathrm{C}_{3}$ and $\mathrm{C}_{4}$ grassland communities with the presence of local afromontane endemics. These are mainly secondary grasslands resulting from deforestation of local shrublands (Ghazanfar and Fisher, 1998). However, some examples of high-altitude primary grasslands exist in suitable habitats. Examples are high-altitude primary low growing mixed grasslands (up to 3,000 m) of the Arabian endemics Festuca 
cryptantha $\left(\mathrm{C}_{3}\right)$, Andropogon crossotos $\left(\mathrm{C}_{4}\right)$, Tripogon oliganthos $\left(\mathrm{C}_{4}\right)$, and cold resistant Stipa spp. $\left(\mathrm{C}_{3}\right)$; grasslands dominated by Andropogon bentii on Socotra $(600 \mathrm{~m})$ and associations of the $\mathrm{C}_{4}$ grass Elionurus muticus with the dwarf shrub Macowania ericifolia (Elionuro muticiMacowanietum ericifoliae) on the mountainous basalt flats in Central Yemen (Deil and Müller-Hohenstein, 1985; Ghazanfar and Fisher, 1998; Brown and Mies, 2012). Examples of tall secondary grasslands in S Arabia are high altitude communities $(2,000-3,000 \mathrm{~m})$ dominated by Themeda triandra, Heteropogon contortus, Andropogon distachyos, Bothriochloa insculpta, Cenchrus unisetus, Hyparrhenia hirta, Arthraxon lancifolius and A. hispidus (Themedo-Hyparrhenietea); dry grasslands dominated by Tetrapogon villosus $\left(\mathrm{C}_{4}\right)$, Elionurus muticus $\left(\mathrm{C}_{4}\right)$, Stipa tigrensis $\left(\mathrm{C}_{3}\right)$, and Cenchrus setaceus $\left(\mathrm{C}_{4}\right)$ and tall monsoon facing grasslands (above $750 \mathrm{~m}$ ) dominated by Themeda quadrivalvis, Apluda mutica, Setaria pumila, Heteropogon contortus, Sporobolus spicatus, and Arthraxon junnarensis (Ghazanfar and Fisher, 1998; Brown and Mies, 2012).

b) In appearance similar $\mathrm{C}_{4}$-grass dominated communities exist on exposed S-facing slopes of Caspian forests (Akhani and Ziegler, 2002). A combination of edaphic and climatic factors, e.g., presence of summer rainfall in one hand and edaphic constraint as a result of rocky substrate with usually poor soil layer in another hand are advantageous for the formation of a $\mathrm{C}_{4}$ grasslands in steep $\mathrm{S}$-facing slopes, dominated by $\mathrm{C}_{4}$ grasses like Bothriochloa ischaemum (Figure 9B), B. bladhii, Cleistogenes serotina (Figure $\mathbf{9 H}$ ), Heteropogon contortus, and Cenchrus orientalis (Figure 8C). The arboreal vegetation is made by $\mathrm{N}$ temperate elements such as Carpinus orientalis, Zelkova carpinifolia, Quercus castaneifolia, Colutea buhsei, Crataegus spp., Cotoneaster spp., and Rosa spp. A comparable vegetation forms in olive orchards in Caspian lowlands as a result of artificial irrigation during summer time have been observed (Akhani, unpublished). The South Caspian $\mathrm{C}_{4}$ grasslands are paralogues to the Mediterranean $\mathrm{C}_{4}$ dominated grassland of the order Cymbopogono-Brachypodietalia ramosi (=Hyparrhenietalis hirtae) (Diez-Garretas and Asensi, 1999; Mucina et al., 2016). In the western Himalayas (E Afghanistan, N Pakistan), where monsoon provides sufficient rainfall, similar grasslands with Cymbopogon, Chrysopogon, Heteropogon, Aristida, etc. grow in association with Acacia modesta and Olea cuspidata woodlands. Chrysopogon-Cymbopogon grasslands are also typical for the uplands of Pakistani Balochistan (Suttie and Reynolds, 2003).

c) Xeromorphic grasslands occur mainly in lowlands of the Arabian Peninsula and in southern Iran. They occur rarely as separate communities but rather with open Acacia pseudosavannas or mixed with shrubs like Calligonum sp., Leptadenia pyrotechnica, or Lycium shawii or with xeromorphic dwarf shrubs like Hammada salicornica and Caroxylon cyclophyllum. The dominating species is the $\mathrm{C}_{4}$ grass Panicum turgidum, which mostly forms pure grass communities or co-occurs with other $\mathrm{C}_{4}$ grasses, like
Lasiurus scindicus, Aristida mutabilis, Dichanthium spp., Cenchrus spp. (Figure 9F), Stipagrostis spp., and Aristida spp. (Kürschner, 1986; Ghazanfar and Fisher, 1998).

4) Meso- and hygrophytic communities are known on river shores, irrigation channels, seasonal rivers, and wadis of Turkmenistan, Afghanistan, Pakistan, and Iran, as well as on non or slightly salty sandy soils with high water-table, close to Caspian shores, with intensive human disturbance, with patches and communities of tall $\mathrm{C}_{4}$ grasses like Imperata cylindrica, Saccharum spontaneum, and Tripidium ravennae. Saccharum spontaneum (Figure 8A) communities often cooccur with Tamarix spp. shrubs or tall $\mathrm{C}_{3}$ grasses, like Phragmites spp. and Arundo donax, and in transition zones, with more constant water-table these patches form sometimes transitions with more hygrophytic $\mathrm{C}_{4}$ sedges, like Cyperus sp. or Fimbristylis sp. (Chaudhri et al., 1966; Nechayeva, 1992; Chandran, 2015). In Israel passes the northern distribution of another important $\mathrm{C}_{4}$ hygrophyte, Cyperus papyrus. Once forming communities together with $\mathrm{C}_{3}$ grasses like Phragmites and Arundo, as well as Typha, its communities unfortunately largely disappeared because of habitat destruction and pollution (Danin and Orshan, 1999). In drier regions of S Iran and Arabia more xerophytic grasses, like Desmostachya bipinnata (Figure 8D), Cymbopogon sp., etc. often replace this kind of vegetation in wadi beds and seasonally flooded plains (Kürschner, 1986; Ghazanfar and Fisher, 1998; Akhani, 2015a).

5) Ruderal $\mathrm{C}_{4}$ communities can be classified as follows: $\mathrm{C}_{4}$ ruderal and weedy communities in irrigated fields or adjacent disturbed places (Figure $8 \mathbf{8}$ ): In most parts of the IranoTuranian region and Caspian lowlands the weedy communities develop during summer times dominated by species of Sorghum, Euphorbia subgen. Chamaesyce (Figure 10E), Bothriochola, Setaria, Eleusine, Echinochloa, Digitaria (Figure 9I), Paspalum, Cynodon, Imperata cylindrica, Cyperus spp., Atriplex spp. (mostly Atriplex tatarica), Portulaca oleracea, Bassia scoparia, Salsola tragus, Suaeda altissima, S. arcuata, Caroxylon spp., Tribulus terrestris, and several Amaranthus species. The species combination varies based on the irrigation regime, soil, and management of weed control. In southern parts of SW Asia the diversity of more thermophilous ruderal grasses like Cenchrus, Panicum, Eragrostis, Dactyloctenium, Chloris (Figure 9G), Sporobolus, Urochloa, Hyparrhenia hirta, Desmostachya bipinnata (Figure 8D) as well as Eudicots like Boerhavia repens, Euphorbia subgen. Chamaesyce, Zaleya pentandra, Trianthema portulacastrum (Figure 10G), Aerva javanica, Suaeda aegyptiaca increases (Nasir and Ali, 1970-2003; Shmida and Aronson, 1986; El-Ghanim et al., 2010; Abdel Khalik et al., 2013; El-Sheikh, 2013).

\section{$\mathrm{C}_{4}$ Eudicots Are Related to Dominance of Continentality Index}

Our findings show different tendencies of $\mathrm{C}_{4}$ Monocot and $\mathrm{C}_{4}$ Eudicot distributions in the study area. The usual pattern of increase of $\mathrm{C}_{4}$ species along a latitudinal gradient is more or less 
similar to global patterns (Pyankov et al., 2010, Figure 6) with deviations mostly due to its complex topography, edaphic factors, and the resulting presence of specific microclimates. The $\mathrm{C}_{4}$ grasses increase along the southern and eastern edges of the region (Yemen, Oman, Pakistan) with higher summer precipitation due to monsoon and tropical climates (Ghazanfar and Fisher, 1998), Figure 6D. In fact, $\mathrm{C}_{4}$-grasslands are known to depend on a dry and rain seasonality, where bushfires during dry seasons on one hand prevent forest growth while high temperatures on the other hand favor $\mathrm{C}_{4}$ grasses (Skinner et al., 2002; Bond et al., 2005; Keeley and Rundel, 2005; Hoetzel et al., 2013). The savanna-like $\mathrm{C}_{4}$ grasslands at the south-eastern corner of the Caspian forests are supported by a small peak of summer precipitation, while the spring flora is dominated by $\mathrm{C}_{3}$ grasses and forbs (Akhani and Ziegler, 2002). The $\mathrm{C}_{4}$ poor but rainfall rich Euro-Siberian portions of SW Asia also favor $\mathrm{C}_{4}$ Monocots over $\mathrm{C}_{4}$ Eudicots. For example, in the north-western edges of the study area the percentage of Monocot species in the local $\mathrm{C}_{4}$ flora may reach $84 \%$ (Zaqatala, Republic of Azerbaijan) ('GBC').

The high proportion of $\mathrm{C}_{4}$ Eudicots in Iran and Turkmenistan may be explained by large saline and sandy deserts and high continentality, which favor halophytic Chenopodiaceae species and psammophytic Calligonum spp. The increase of $\mathrm{C}_{4}$ Eudicots in W-E direction even in similar longitudinal belts may be explained by a combination of edaphic and climatic conditions (compare the opposite tendency in China, Wang and Ma, 2016). Indeed, the continentality index clearly increases along a W-E direction over the SW Asia to Central Asia (Djamali et al., 2011; Djamali et al., 2012). The harsh summer times with scarcity of fresh water resources in deserts of Iran and Turkmenistan reduce the competitive advantages of $\mathrm{C}_{3}$ species (Pyankov et al., 2010; Sage and Sultmanis, 2016). Additionally, absence of summer rainfall supresses $\mathrm{C}_{4}$ grassland formation. Although higher continentality adversely affects general $\mathrm{C}_{4}$ domination (Figure 6C), this is not the case for $\mathrm{C}_{4}$ Chenopodiaceae, which are adapted to temperate deserts with continental climate (Figure 6A). This is explained by the phenology of chenopods with an estival active growing season (Toderich et al., 2007). Many chenopods and species of Calligonum are highly specialized by their morpho-anatomical and physiological traits to live under harsh conditions (e.g., their long root systems have access to the underground and subsurface water-table) (Gintzburger et al., 2003; Soskov, 2011). The negative correlation of $\mathrm{C}_{4}$ Cyperaceae with continentality (Figure 6B) and positive correlation with average annual temperature relate to their sensitivity to low winter temperatures (Wang and $\mathrm{Ma}, 2016$ ). $\mathrm{C}_{4}$ Cyperaceae however do not seem to be unaffected by precipitation. The later may be explained by a high variety of ecotypes within $\mathrm{C}_{4}$ Cyperus (the main bulk of $\mathrm{C}_{4}$ Cyperaceae), ranging from psammophytic xerophytes to hygrophytes limited to permanent wetlands and the consequent species shift in relation to various ecological conditions.

Finally, it is interesting to note, that while different metabolic subtypes often indicate the adaptation of $\mathrm{C}_{4}$ Monocots to specific ecological conditions, e.g., NADP-ME Monocots are more likely distributed in areas with high rainfall, while NAD-ME Monocots grow in conditions with lower rainfall (Schulze et al., 1996), this feature doesn't seem indicative in $\mathrm{C}_{4}$ Eudicots E.g., xerophytic $\mathrm{C}_{4}$ chenopods show both NAD-ME or NADP-ME metabolisms (see Supplementary Appendix Table 1).

\section{Southwest Asia-Center of Biodiversity of Single-Cell $\mathrm{C}_{4}$ and $\mathrm{C}_{3}-\mathrm{C}_{4}$ Switching Plants}

One of the fascinating aspects of $\mathrm{C}_{4}$ photosynthesis is the discovery of Single-Cell functioning $\mathrm{C}_{4}$ photosynthesis in two $\mathrm{C}_{4}$ lineages of the Chenopodiaceae (Voznesenskaya et al., 2001; Edwards et al., 2004; Akhani et al., 2005). This photosynthetic type was described for the first time in Suaeda aralocaspica (Bunge) Freitag and Schütze (= Borszczowia aralocaspica Bunge), a hygrohalophyte from the saline depressions of Central Asian semideserts (Freitag and Stichler, 2000; Voznesenskaya et al., 2001). Bienertia as a monophyletic lineage in which all species perform single-cell functioning $\mathrm{C}_{4}$ was discovered shortly after $S$. aralocaspica with some new species (Voznesenskaya et al., 2002; Akhani et al., 2003; Akhani et al., 2005; Kapralov et al., 2006; Akhani et al., 2012). The genus Bienertia is diversified mostly in Iran and some surrounding areas often on moist and highly saline soils in association with several annual $\mathrm{C}_{4}$ chenopods belonging to Caroxylo-Climacopteretea class in the interior Iran or on open habitats of saline shrublands on the lowlands around the Persian Gulf between Tamarix species or on tidal shores (Akhani et al., 2003; Akhani et al., 2009).

Instead of a conventional system of $\mathrm{C}_{4}$ terrestrial species, having a dual-cell compartment consisting of mesophyll and bundle sheath cells, in both single-cell $\mathrm{C}_{4}$ lineages, this achieved by localizing photosynthetic machinery in a single-cell type. In Suaeda aralocapica dimorphic chloroplasts are polarized in a single layer mesophyll cell, in which the proximal chloroplasts fix $\mathrm{CO}_{2}$ using PEPC into a $\mathrm{C}_{4}$ acid which moves to distal chloroplasts via a cytoskeleton network (Edwards et al., 2004; Chuong et al., 2006). Similarly, the Bienertia species single-cell system has a unique form in which lateral chloroplasts function as mesophyll cells and a bubble-like central chloroplast compartment (CCC) acts as Kranz-cells in usual $\mathrm{C}_{4}$ species. This discovery stimulated scientists to deeply investigate the biology and genomics of this simplified system, which might have advantages for those looking for genetic engineering of $\mathrm{C}_{4}$ photosynthesis in $\mathrm{C}_{3}$ crop plants (Schuler et al., 2016).

Another peculiarity within the $\mathrm{C}_{4}$ plants of SW and Central Asia, is the presence of two types of photosynthesis within the life cycles of particular lineages and species of Chenopodiaceae. In these species $\mathrm{C}_{3}$ cotyledon leaves are replaced by $\mathrm{C}_{4}$ shoots. This characteristic is widespread in the subfamily Salsoloideae and rarely in Suadedoideae (Pyankov et al., 1999; Pyankov et al., 2000b; Pyankov et al., 2001; Akhani and Ghasemkhani, 2007). In both tribes of Salsoleae and Caroxyleae several genera, such as Haloxylon, Halothamnus, Hammada, Girgensohnia, Noaea and Soda inermis (Salsola soda), Climacoptera, Halimocnemis, Petrosimonia, Kaviria, and Halocharis are known to have this switching mechanism. In Suaedoideae, this type was known in 
Suaeda microphylla evidenced by carbon isotope values (Akhani and Ghasemkhani, 2007) or anatomy (Khoshravesh and Akhani, unpublished data). As this characteristic is of interest for gene engineering, the transcriptomes of Haloxylon ammodendron and Soda inermis (Salsola soda) have been studied (Li et al., 2015; Lauterbach et al., 2017).

Ecologically, the development of a switching mechanism from a $\mathrm{C}_{3}$ to a $\mathrm{C}_{4}$ photosynthetic metabolism hasn't however received much attention. Switching chenopods are mainly halophytes and xerohalophytes of continental temperate saline ecosystems (Climacoptera, Petrosimonia, Halimocnemis, Soda inermis), gypsiferous (Halothamnus), and sandy (Haloxylon) habitats of the Irano-Turanian floristic region and are taxonomically among the main and most biodiverse taxa of SW Asian $\mathrm{C}_{4}$ Eudicots. Switching plants are also among the main biomass producers in the Irano-Turanian deserts, suggesting that the switching mechanism may imply an evolutionary advantage to those species. The continental climates of their habitats may probably favor a switching mechanism and the presence of $\mathrm{C}_{3}$ cotyledons at early developmental stages, when germination at low temperatures favors the presence of $\mathrm{C}_{3}$ cotyledons while increasing temperatures during the growth period favor $\mathrm{C}_{4}$ leaves (Akhani and Ghasemkhani, 2007). Further investigations however are needed to comprehend better the ecological advantages in comparison with tropical deserts.

\section{Palaeoclimatic Implications}

The distribution pattern of $\mathrm{C}_{4}$ plants in SW Asia is at least partly related to the palaeoclimatic conditions which have prevailed in the region during the Neogene. Today, the region is dominated by the summertime subtropical anticyclones (Zarrin et al., 2009) which induce a long summer drought in most parts of SW Asia. The subtropical anticyclonic system is particularly intensified and maintained by the high elevations in SW Asia (Zarrin et al., 2011) which are mostly present since at least 7 million years ago (Djamali et al., 2012). During the late Neogene, a long summer drought has thus dominated over the region impeding the penetration of moisture-bearing westerlies into the IranoAnatolian inlands and Central Asia. The continental inlands of SW Asia, although close to the Indian Ocean, receive no monsoon precipitation during the summertime because of the complex monsoon-desert mechanism described by Rodwell and Hoskins (1996). The palaeoclimatic archives suggest that excepting the Arabian Peninsula, most of the continental interior of SW Asia has not received summer monsoon rainfall during the intensification phase of the latter at the beginning of the Holocene (Djamali et al., 2010). Only SE Iran might have received some direct summer precipitation from the summer monsoons some 11,400 to 6,500 years ago (Vaezi et al., 2019). Some of the $\mathrm{C}_{4}$ plant communities found in currently dry areas of S Iran and Arabian Peninsula (see above) may be the relicts of formerly widespread $\mathrm{C}_{4}$ communities when the area received more summer rainfall. Relatively higher values of $\delta^{13} \mathrm{C}$ of organic matter in the Jazmurian playa sediments during the early Holocene (Figure 8A in Vaezi et al., 2019) may indeed reflect the important contribution of more abundant $\mathrm{C}_{4}$ grasses during the Indian Monsoon intensification phase in SE Iran. With the exception of increasing summer rains in SE Iran and Arabia, it seems thus that most of SW Asia has always been subjected to long summer droughts and high continentality since several million years (Djamali et al., 2012). Such long-lasting geoclimatic conditions are characterized by strong continentality, long summer droughts and presence of intracontinental endorheic basins which support the formation of a broad range of saline environments suitable for the diversification and specialization of $\mathrm{C}_{4}$ Eudicots in particular the halophytic chenopods.

\section{Human Utilization of $\mathrm{C}_{4}$ Plants in Southwest Asia}

SW Asia including the Fertile Crescent had a long history of plant domestication and land use (Zohary and Hopf, 2000). Deserts and steppe populations utilize many $\mathrm{C}_{4}$ species in a variety of ways, as source for food, fire wood, for grazing, construction, greening of their surroundings, medicine, and in recent times for desert reclamation programs and afforestation. They have additional potentials such as usage as biofuel, genetic engineering practices and even invention of new crops. $\mathrm{C}_{4}$ crops exploited in SW Asia either natively originated or widely distributed or imported from other parts of the world together with their main applications are listed in the Supplementary Table 4. It has to be noted, that although the wild forms of many $\mathrm{C}_{4}$ crops, like Eragrostis tef, Echinochloa frumentacea, Panicum miliaceum, Eleusine coracana, Setaria italica, Soda inermis, etc. are distributed throughout SW Asia, they are mostly cultivated outside of this region.

The most important and most species rich group of $\mathrm{C}_{4}$ crops are millets and millet-like cereals cultivated traditionally for their grain in arid areas of S Asia and Africa. Among them several major millet crops like sorghum (Sorghum bicolor) (Sanjana Reddy, 2017a), proso millet (Panicum miliaceum) (Gomashe, 2017), foxtail millet (Setaria italica) (Hariprasanna, 2017), and pearl millet (Cenchrus americanus) (Sanjana Reddy, 2017b) made it to fame out of their region of domestication and have been introduced not only to SW Asia but are extensively cultivated worldwide for their grains. Sweet sorghum (Sorghum bicolor) is also an alternative source of syrup and sugar (Sanjana Reddy, 2017a), although the main pantropical sugar crop remains the extensively cultivated sugarcane (Saccharum officinarum) (James, 2014). Although the wild forms of small millets, are distributed in SW Asia, they are mainly cultivated as traditional cereals of cultural significance outside of this area (Seetharam and Riley, 1986). In fact, they form important grain crops in the traditional communities of S Asia and Subsaharan Africa. An interesting example is cultivation of teff (Eragrostis tef) concentrated in Ethiopia and Eritrea, where it is of the most important crop plants and is used mainly for the production of traditional Injera flat bread (Seetharam and Riley, 1986). Teff recently however is wining fame as a healthy alternative cereal outside of E Africa. Molecular studies have shown that this allotetraploid is closely related to Eragrostis pilosa, growing in SW Asia (Ingram and Doyle, 2003; Assefa et al., 2017). 
Millets cultivated on smaller scales in SW Asia include finger millet (Eleusine coracana), Indian barnyard millet (Echinochloa frumentacea), Japanese millet (E. esculenta), and adlay millet (Coix lacryma-jobi). Their cultivation in SW Asia is mainly limited to regions where they bear cultural significance, such as the plains and hills of Afghanistan and Pakistan (Breckle and Rafiqpoor, 2010; Breckle et al., 2013). Corn (Zea mays) is the world's most important $\mathrm{C}_{4}$ grain crop and SW Asia is not an exception, where it is extensively cultivated (Staller, 2010).

Many wild SW Asian $\mathrm{C}_{4}$ grasses are important fodder and pasture crops, for biomass production or used for landscape greening on large and small scales in arid areas of $\mathrm{N}$ America, Australia, S Europe, Central Asia, India, and Subsaharan Africa, namely Bouteloua curtipendula, Cenchrus spp., Chloris gayana, Cynodon dactylon, Diplachne fusca, Lasiurus scindicus, Panicum antidotale, Setaria viridis, Sorghum halepense and Sporobolus spp. They may present a source for further millet and forage grass breeding and cultivation for forage and erosion control in disturbed and desertifying areas of SW Asia.

The $\mathrm{C}_{4}$ Monocots are of high importance for summer grazing of wildlife such as Persian Ibex or livestock on steep rocky outcrops and disturbed or degraded South Caspian forests (Akhani and Ziegler, 2002). Grazing on salt marsh grasslands dominated by Aeluropus is common in most parts of the region (Whigham et al., 1993).

The Saharo-Sindian and Somali-Masai vegetations of SW Asia are rich in highly productive high biomass Monocots. Genera like Panicum, Cenchrus, Desmostachys bipinnata, Saccharum, Tripidium, Mischanthus, Paspalum, Pogonatherum, and Cyperus are high biomass producers that both have a value for grazing and industrial applications (Serag, 2003; Tubeileh et al., 2016; Mullet, 2017).

Haloxylon persicum, H. ammodendron, Xylosalosla richteri, and Calligonum spp. may yield up to $1.2 \mathrm{t}, 3.0 \mathrm{t}, 1.3$, and $1.2 \mathrm{t}$ green biomass per hectare respectively, depending on habitat type and population density. Haloxylon ammodendron is definitely the largest species by biomass and can reach a height of up to $9 \mathrm{~m}$ and an age of up to 100 years (Fet and Atamuradov, 1994; Gintzburger et al., 2003) (Figure 8K).

Additionally, psammophytic Xylosalsola sp. in Turkmenistan and Central Asia and Soda stocksii (Salsola stocksii) and Hammada salicornica in Pakistan and India are grown for the same purpose. Haloxylon ammodendron is mainly cultivated in Central Asia, SE Europe, NW China, and Iran for as erosion control and forage on salt and clay deserts, saline flats, and saline sands. From the Mediterranean toward Iran Atriplex spp. like A. halimus and $A$. canescens are cultivated for the same purpose on saline clayey soils (Hanelt, 2001; Danin, 2007; Walker et al., 2014). Bassia prostrata has been cultivated in Turkmenistan, Central Asia, Europe, and the USA as forage and erosion control on clayey, slightly saline, sandy, and rocky soils (Dzyubenko and Soskov, 2014).

Several $\mathrm{C}_{4}$ crops are gaining importance as healthy food plants. To mention are seeds of Amaranthus caudatus, A. cruentus, and $A$. hypochondriacus, used as gluten-free pseudocereals with increasing cultivation worldwide (Sauer,
1967). Furthermore, several $\mathrm{C}_{4}$ Eudicots are cultivated as leaf vegetables. E.g., Portulaca oleracea is cultivated around the Mediterranean, in Iran, Turkey, and Transcaucasia (Gonnella et al., 2010; Uddin et al., 2014). Suaeda aegyptiaca is cultivated in southern Iran and Amaranthus tricolor in Pakistan, India, and E Asia for food (Akhani, 2006). Soda inermis, growing on saline soils throughout Armenia, Iran, Turkey, and Turkmenistan, is cultivated and highly prized as a leaf vegetable (agretti) in the Mediterranean region (Centofanti and Bañuelos, 2015). Another chenopod, the common ruderal and ornamental Bassia scoparia, is cultivated for the production of a caviar substitute in E Asia ("Useful Temperate Plants Database"; Han et al., 2006; Nedelcheva et al., 2007). Recent efforts have also been done to introduce locally collected leaf vegetables (Cleome gynandra, Boerhavia sp. and Sesuvium sesuvioides) and medicinal plants [Blepharis sp. (Figure 10F) and Tribulus terrestris] into cultivation (Hanelt, 2001; Cheikhyoussef et al., 2011; Mahesh et al., 2012; Boteva et al., 2014; Kripa and Vijayalakshmi, 2016; Salamon et al., 2016; 'PROTA4U web database', 2018). Furthermore, tuber bearing sedges, like Cyperus esculentus are interesting candidates as food crops, already cultivated throughout the world (Pascual et al., 2000; Arafat et al., 2009). Several $\mathrm{C}_{4}$ Eudicots [e.g., Gisekia pharnacoides, Hypertelis cerviana, Suaeda spp., Tecticornia indica, Atriplex spp., and Soda and Salosla spp.], are used locally as famine foods or collected as local leaf vegetables and may be interesting for further investigations as crop plants (Hanelt, 2001; "PROTA4U web database", 2018; "Useful Temperate Plants Database"). Some $\mathrm{C}_{4}$ plants are cultivated worldwide for their essential oils, such as Cymbopogon spp. (citronella oil, palmarosa oil, etc.), Chrysopogon gryllus, Chrysopogon zizanioides (vetiver oil), and Cyperus articulatus (Duke, 1993; Hanelt, 2001; Simpson and Inglis, 2001; Bertea and Maffei, 2009; Atala, 2012; Pareek and Kumar, 2013). Some local species of Cymbopogon are already used in local medicine for their aromatic properties and may be of interest for introduction into cultivation (El-Kamali et al., 2005; Bertea and Maffei, 2009; Prasad et al., 2014). A number of $\mathrm{C}_{4}$ species are also favored for their biomass and as a source of fiber, mat, basket weaving, broom, and construction materials, and could be interesting candidates for the diversification of local agriculture. E.g., Bassia scoparia, Cyperus corymbosus, C. malaccensis, C. pangorei, Desmostachya bipinnata and Eulaliopsis binata, and Sorghum bicolor are already cultivated for fibers and high quality mat weaving in Iran, India, and Africa (Wendrich, 1989; Ravichandran et al., 2005; Sahu et al., 2010; Jana and Puste, 2014; Khyade et al., 2018; Shioya et al., 2019).

Finally, some $\mathrm{C}_{4}$ plants are frequently grown ornamentals (e.g., Cyperus alternifolius, C. papyrus, Bouteloua gracilis, B. curtipendula, Stenotaphrum secundatum, Coix lacryma-jobi, Imperata cylindrica, Miscanthus nepalensis, Miscanthus sinensis, Schizachyrium scoparium, Setaria palmifolia, Tripiduium ravennae, Amranthus caudatus, A. tricolor, Gomphrena globosa, G. haageana, B. scoparia, Portulaca pilosa and $P$. grandiflora).

With climate change, overpopulation and resource mismanagement, SW Asia is highly in need of alternative, 
drought, and salt resistant crops to make agriculture more sustainable. A series of $\mathrm{C}_{4}$ crops, in addition to those already introduced and cultivated in SW Asia, are highly interesting for further introduction into cultivation, since their wild forms are already distributed and adapted to SW Asian climate conditions.

\section{Conservation}

Being mainly part of the so-called MENA Region (Middle East and North Africa), SW Asia with its xeric climates is highly susceptible to climate change ( $\mathrm{Pal}$ and Eltahir, 2016). Although future scenarios vary, concerning the degree of climatic changes, a general consensus on the increase of mean temperatures and heat extremes exist (Evans, 2009; Waha et al., 2017). The same is regarding the decrease of precipitation and increase of drought and aridity, with the exceptions of the southern shores of SW Asia, where the increase of monsoon precipitation due to a shift of the inter-tropical convergence zone is expected to occur according to some predictions (Waha et al., 2017; Byrne et al., 2018). The effects of climate change are enhanced by growing population and an aggressive mismanagement of water and land resources. For example, in Iran an ineffective irrigation agriculture, extensive dam construction and groundwater overuse has led to a significant decrease of groundwater levels and the drying and destruction of the main lake, river, and wetland ecosystems (Motagh et al., 2008; Madani, 2014; Akhani, 2015b; Motagh et al., 2017). On the other hand, the SW Asian $\mathrm{C}_{4}$ flora, although highly specialized, is very susceptible to minor changes in many extreme habitats (groundwater levels, period, and amount of precipitation, etc.).

Of the $923 \mathrm{C}_{4}$ species of SW Asia, 141 (105 Eudicot and 36 Monocots-15.3\%) are endemic to SW Asia, while 70 species (50 Eudicots and 20 Monocots-7.6\%) are strict country endemics with very limited habitats. However, even some species distributed beyond SW Asia (e.g., several Cyperus species described from limited areas of the Somali-Masai floristic region) show very restricted distributions. The strict country endemics can be grouped mainly in two subgroups: a) $\mathrm{C}_{4}$ Eudicots (mainly chenopods) mainly endemic to habitats of the Irano-Turanian floristic region; b) $\mathrm{C}_{4}$ Monocots (mainly Poaceae) endemic to the Somali-Masai floristic region (of those the half of the species are endemic to the island of Socotra). Under high climatic and anthropogenic pressure on the narrow habitats of SW Asian $\mathrm{C}_{4}$ endemics, many such species are critically endangered.

As an example, the recently discovered Bienertia kavirense Akhani (Figure 10J), restricted to a narrow region within Iran's central saline desert, has been declared critically endangered from its discovery (Akhani et al., 2012). According to our own documentation in a saline flat located $60 \mathrm{~km} \mathrm{~W}$ of Tehran near Rude Shur (saline river), a very dense subpopulation of Bienertia cycloptera in 2003 completely disappeared in 2009 (Akhani et al., 2003; Akhani, 2016; Akhani and Rudov, 2018) apparently due to dropping of underground water levels. This tragic situation is observed in many similar habitats, where dropping of underground and subsurface water levels affects soil moisture and is consequently a threat for existence of many $\mathrm{C}_{4}$ annuals.
Recent field trips of the authors discovered, that the narrow habitats of Halimocnemis alaeflava and Halimocnemis azerbaijanensis have been fragmented and partly destroyed by factory construction, complete removal of upper soil layers, as well as road and dam construction. In fact, if further localities of $H$. alaeflava are not discovered in future, there is a probability of its complete extinction as its type habitat is on the way toward complete destruction. Another critical example is a subpopulation of the local endemic Caroxylon abarghuense (Figure 10K) in Touran Biosphere Reserve, located in Central East of Iran. In a small valley dominated by Tamarix shrubs, only 16 living individuals of $C$. abarghuense have been found. Their seeds do not seem germinable probably because allee effect resulted from small size population. A subpopulation of Piptoptera turkestana, discovered in 1989 on sandy dunes of central Iran, ca. $30 \mathrm{~km}$ ESE of Kashan, could not be recollected in the same place after extensive searches and apparently disappeared from the locality probably due to habitat disturbance and oil mulching (Figure 11A). Several taxa (e.g., Climacoptera zenobiae) lack proper assessment and are known from very limited collection samples. Species like Climacoptera czelekenica Pratov, being island endemics, depend on the changing water level of the Caspian Sea. On the island of Socotra, the high number of endemic plants is threatened by both climate change and overgrazing (Attorre et al., 2007; Rejzek et al., 2016). This directly affects also the $\mathrm{C}_{4}$ endemics of Socotra, being all $\mathrm{C}_{4}$ grasses. Conservation of endangered $\mathrm{C}_{4}$ endemics is further complicated by the lack of proper population assessment in many regions of SW Asia because of lacks of interest and founding and specially because of inaccessibility due to long lasting military conflicts. The two of the four most endemic rich countries (Afghanistan and Yemen) are both long time battle grounds.

Additional threats to the local $\mathrm{C}_{4}$ flora are introduced and invasive $\mathrm{C}_{4}$ plants. The introduced $\mathrm{C}_{4}$ flora of SW Asia (68 species) is mainly composed of Poaceae (34 species), Amaranthaceae sensu stricto (20 species), and Euphorbiaceae (7 species) (Pahlevani et al., 2020). Several $\mathrm{C}_{4}$ lineages not typical for the region have been introduced to $\mathrm{SW}$ Asia $\left(\mathrm{C}_{4}\right.$ Flaveria clade $\mathrm{A}, \mathrm{C}_{4}$ Alternanthera, and Gomphrena). The genus Amaranthus, although a neophytic genus in most areas of SW Asia, includes not only recently introduced species but also apparently old neophytes (e.g., A. blitum) and local species (e.g., A. graecizans, A. tenuifolius, A. sparganicephalus). Of the 67 introduced $\mathrm{C}_{4}$ species at least 48 have been reported to be invasive in various regions of the world ("CABI-Invasive Species Compendium. Wallingford, UK: CAB International"; Elmore and Paul, 1983). These species may form a major threat to local floras and economic burdens for agriculture and livestock. An important aspect of invasiveness in the area is introducing $\mathrm{C}_{3}$ invasive species into $\mathrm{C}_{4}$ habitats. This happened in S Iran and Pakistan where introduction of Prosopis juliflora occupied many of the habitats of drought resident species including native $\mathrm{C}_{4}$ species.

The saline areas, sandy dunes, and marl or gypsum habitats, where the majority of $\mathrm{C}_{4}$ Eudicots grow, have no protection 


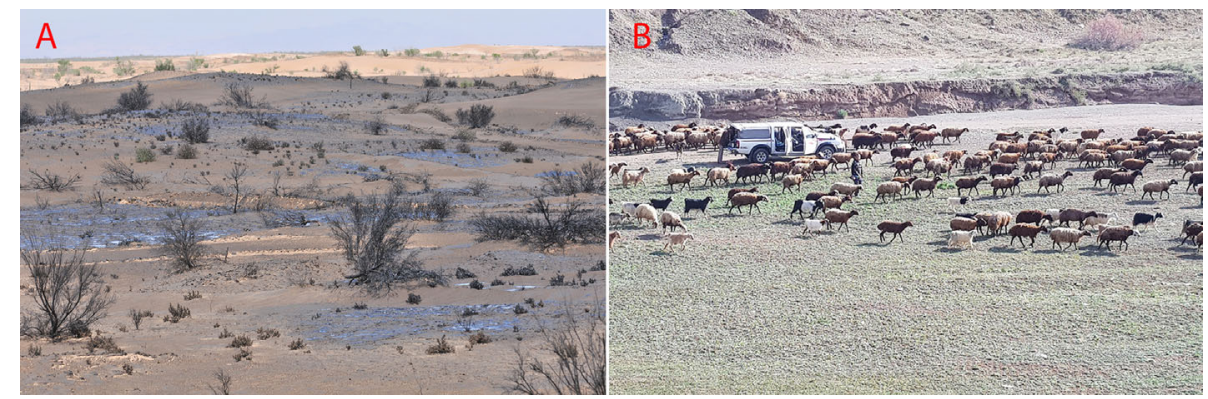

FIGURE 11 | (A, B): Mismanagement of $\mathrm{C}_{4}$ habitats in Iran. (A) Oil mulching in sand dunes with rich $\mathrm{C}_{4}$ plant species in Abuzeidabad, Kashan, Central deserts of Iran, 28.5.2020. (B) Overgrazing in gypsum and salty ground between Zanjan and Mianeh, Northeast (NE) Iran, 14.4.2018. (Photos by H. Akhani).

priority in most of the countries of SW Asia. Mostly, these habitats are considered as badlands with poor biodiversity. Grazing and shortage of water are big problems affecting the vegetation in such habitats. Therefore, most of these lands with poor vegetation cover are converted into dust emission centers with a huge environmental concern (Akhani, 2015b). An example of mismanagement of such habitats we refer to intensive oil mulching in many sand dunes in Iran with dense $\mathrm{C}_{4}$ plant vegetation. Such activities which aim to control dune movement result in destroying natural flora with many $\mathrm{C}_{4}$ annuals and shrubs (Figure 11A). Sadly, improper managements threatened many gypsophytic, halogypsophytic, and xerophytic hill habitats, which are the main habitats of endemic $\mathrm{C}_{4}$ chenopods (Akhani, 2006; Ghorbanalizadeh et al., 2020) (Figure 11B). We strongly recommend re-evaluation of protection policies to restore and protect $\mathrm{C}_{4}$-rich habitats that are of high advantage in desert areas because of their low water requirements and vegetation cover provision during harsh seasons.

\section{CONCLUSIONS}

SW Asia is not only an area of origin and diversification of most interesting and highly adapted $\mathrm{C}_{4}$ Eudicot lineages, but also provide diverse and vast habitats for growing $\mathrm{C}_{4}$ Monocots. The evolution of various eco-morphological traits among $\mathrm{C}_{4}$ Eudicots lineages (notably single-cell functioning $\mathrm{C}_{4}$ plants and switching $\mathrm{C}_{3}-\mathrm{C}_{4}$ species) and the presence of many endemic species are indicative of long-lasting ecological pressure that supports speciation and specialization among different families in particular Chenopodiaceae and Calligonum (Polygonaceae).

The $\mathrm{C}_{4}$ Eudicots are known to dominate vast Irano-Turanian deserts. Our data suggest, that this is mainly related to the adaptation of $\mathrm{C}_{4}$ Eudicots to the continental climatic conditions of the Irano-Turanian deserts in contrast with the $\mathrm{C}_{4}$ Poaceae, that dominate areas with the presence of summer rainfall in the southern and southeastern parts of the area influenced by monsoon summer rains.

Unfortunately, the SW Asian $\mathrm{C}_{4}$ plant diversity is threatened by the impact of intensive land use synergized by global warming and rapid desertification. In spite of our knowledge on the taxonomy and phylogeny of many $\mathrm{C}_{4}$ lineages, many questions regarding SW Asian $\mathrm{C}_{4}$ plants are however still unresolved. For example, the taxonomy of the genera Calligonum, Climacoptera, Hammada, Kaviria, Caroxylon, and Tribulus needs still to be clarified. More studies are necessary to understand the phylogenetic relationships of $\mathrm{C}_{3}$ and $\mathrm{C}_{4}$ species of the genera Fimbristylis, Polycarpaea and clarify ambiguities in presence of some $\mathrm{C}_{3}$ and $\mathrm{C}_{3}-\mathrm{C}_{4}$ intermediate lineages within prevalently $\mathrm{C}_{4}$ Salsoloideae (Chenopodiaceae). The study of the vegetation of some neglected areas and the description of some specific $\mathrm{C}_{4}$ plant dominated communities as well as the compilation of some country floras in the region (e.g., Syria, Jordan) would be highly informative.

Due to political instability and low interest in the conservation of desert areas with lower biodiversity, several rare $\mathrm{C}_{4}$ endemics are under the threat of extinction. Being part of the ecologically and climatically vulnerable MENA region, SW Asia is also in need of a sustainable management of water resources and agriculture. The $\mathrm{C}_{4}$ dominated habitats requires protection priority and monitoring of highly adapted plants to harsh environments. We re-emphasize the importance of regional $\mathrm{C}_{4}$ crops and the selection of new $\mathrm{C}_{4}$ crop candidates with lesser ecological impact than genetic engineering as a much more sustainable approach to guarantee the food security facing the future global change.

\section{DATA AVAILABILITY STATEMENT}

The original contributions presented in the study are included in the article/supplementary material; further inquiries can be directed to the corresponding author.

\section{AUTHOR CONTRIBUTIONS}

AR provided the data, wrote the first draft, prepared all figures and tables. HA planned and supervised the research, contributed to the preparation of the data and text, provided all photos, edited the text and jointly worked together in writing of first 
draft. MM analyzed all the carbon isotopes in the paper, read, and edited the manuscript. MD contributed to the writing of the palaeoecology part of the paper.

\section{FUNDING}

This research was funded by postdoctoral support for the first author by the International Office of the University of Tehran and the Erasmus Mundus Marhaba Program.

\section{ACKNOWLEDGMENTS}

The authors thank the curators of the Royal Botanic Garden Edinburgh Herbarium (E) and the Herbarium of Russian Academy of Sciences - V. L. Komarov Botanical Institute (LE) for the provided plant samples, the Iranian National Science Foundation for a travel support to St. Petersburg Herbarium (AR), Sibald Trust for a herbarium visit to Edinburgh Botanical Garden (HA) and LIA HAOMA CNRS Project for funding the isotopic analyses. We would like to thank Mr. Denis Fiorillo at the SSMIM/MNHN for the isotopic measurements and Dr Marie Balasse who authorised us to use the facilities of this Laboratory. We also appreciate the help of Dr. Claudia Deigele (Munich) for providing us the unpublished carbon isotope database of late Prof. Hubert Ziegler. Finally, we would like to thank Dr. David A. Simpson (Royal Botanical Gardens Kew) for his precious

\section{REFERENCES}

Abdel Khalik, K., El-Sheikh, M., and El-Aidarous, A. (2013). Floristic diversity and vegetation analysis of Wadi Al-Noman, Mecca, Saudi Arabia. Turkish J. Bot. 37, 894-907. doi: 10.3906/bot-1209-56

Akhani, H., and Deil, U. (2012). First observations of the flora and vegetation of three Islands in the NW Persian Gulf (Iran). Phyton 52, 73-99.

Akhani, H., and Ghasemkhani, M. (2007). Diversity of photosynthetic organs in Chenopodiaceae from Golestan National Park (NE Iran) based on carbon isotope composition and anatomy of leaves and cotyledons. Nova Hedwigia $131,265-277$.

Akhani, H., and Rudov, A. (2018). Biodiversity Conservation or Biotechnology: What is Iran's priority today? Strategic Res. J. Agric. Sci. Natural Resour. 3 (2), 181-194. doi: 10.1007/s11120-008-9376-0

Akhani, H., Trimborn, P., and Ziegler, H. (1997). Photosynthetic pathways in Chenopodiaceae from Africa, Asia and Europe with their ecological, phytogeographical and taxonomical importance. Plant Syst. Evol. 206, 187221. doi: $10.1007 / \mathrm{BF} 00987948$

Akhani, H., Ghobadnejhad, M., and Hashemi, S. (2003). Ecology, Biogeography and Pollen Morphology of Bienertia cycloptera Bunge ex Boiss. (Chenopodiaceae), an Enigmatic $\mathrm{C}_{4}$ Plant without Kranz Anatomy. Plant Biol. 5, 167-178. doi: 10.1055/s-2003-40724

Akhani, H., Barroca, J., Koteyeva, N., Voznesenskaya, E., Franceschi, V., Edwards, G., et al. (2005). Bienertia sinuspersici (Chenopodiaceae): A New Species from Southwest Asia and Discovery of a Third Terrestrial C4 Plant Without Kranz Anatomy. Syst. Bot. 30, 290-301. doi: 10.1600/0363644054223684

Akhani, H., Edwards, G., and Roalson, E. (2007). Diversification of the Old World Salsoleae s.l. (Chenopodiaceae): Molecular Phylogenetic Analysis of Nuclear and Chloroplast Data Sets and a Revised Classification. Int. J. Plant Sci. 168, 931-956. doi: 10.1086/518263

Akhani, H., Lara, M. V., Ghasemkhani, M., Ziegler, H., and Edwards, G. E. (2009). Does Bienertia cycloptera with the single-cell system of C-4 photosynthesis personal communication on the Cyperaceae of the Arabian Peninsula and Socotra, Targol Chatrenoor for her advices on the list of Climacoptera species and Roxana Khoshravesh for her critical suggestion to improve this paper.

\section{SUPPLEMENTARY MATERIAL}

The Supplementary Material for this article can be found online at: https://www.frontiersin.org/articles/10.3389/fpls.2020. 546518/full\#supplementary-material

SUPPLEMENTARY APPENDIX TABLE 1 | Complete List of C4 plants in Southwest Asia showing their $\mathrm{C}_{4}$ lineage, life form, chorotype, endemism, ecotype, $\delta^{13} \mathrm{C}$ and $\mathrm{C}_{4}$ subtype and respective leaf or shoot anatomical type.

SUPPLEMENTARY FIGURE 1 | Climatic diagrams of selected 29 stations in different parts of SW Asian countries obtained from of the Iranian Meterorological Organization (IRIMO), Scholte and De Geest (2010) and Raza et al. (2015).

SUPPLEMENTARY TABLE 2 | List of Polycarpaea (Caryophyllaceeae) species known from SW Asia which we could not test their photosynthetic type because of absence of material.

SUPPLEMENTARY TABLE 3 | The List of Polycarpaea (Caryophyllaeceae), Cyperus and Fimbristylis (Cyperceae) species with $\mathrm{C}_{3}$ type carbon isotope values.

SUPPLEMENTARY TABLE 4 | List of $\mathrm{C}_{4}$ plants with economic importance in SW Asia including non-native cultivated or introduced species.

SUPPLEMENTARY DATA SHEET 1 | References of floristic database.

exhibit a seasonal pattern of delta C-13 values in nature similar to co-existing C-4 Chenopodiaceae having the dual-cell (Kranz) system? Photosynth. Res. 99, 23-36. doi: 10.1007/s11120-008-9376-0

Akhani, H., Chatrenoor, T., Dehghani, M., Khoshravesh, R., Mahdavi, P., and Matinzadeh, Z. (2012). A new species of Bienertia (Chenopodiaceae) from Iranian salt deserts: A third species of the genus and discovery of a fourth terrestrial $\mathrm{C}_{4}$ plant without Kranz anatomy. Plant Biosyst. 146, 1-10. doi: 10.1080/11263504.2012.662921

Akhani, H., Greuter, W., and Roalson, E. H. (2014). Notes on the typification and nomenclature of Salsola and Kali (Chenopodiaceae). Taxon. 63, 647-650. doi: 10.12705/633.1

Akhani, H., and Ziegler, H. (2002). Photosynthetic pathways and habitats of grasses in Golestan National Park (NE Iran), with an emphasis on the C 4 -grass dominated rock communities. Phytocoenologia 32, 455-501. doi: 10.1127/0340-269X/2002/0032-0455

Akhani, H. (2004). Halophytic vegetation of Iran: Towards a syntaxonomical classification. Annali di Botanica 4, 65-82.

Akhani, H. (2006). "Biodiversity of halophytic and sabkha ecosystems in Iran," in Tasks for Vegetation Science. Sabkha Ecosystems Volume II (West and Central Asia: Springer), 71-88. doi: 10.1007/978-1-4020-5072-5_6

Akhani, H. (2015a). Plants and Vegetation of North-West Persian Gulf: The coasts and Islands of Khore Musa (Mahshahr and Adjacent Areas: University of Tehran Press).

Akhani, H. (2015b). Iran's environment under siege. Science 350, 392-392. doi: $10.1126 /$ science.350.6259.392-a

Akhani, H. (2016). "Plant diversity of saline wetlands and salt marshes of Iran," in U.S.-Iran Symposium on Wetlands. Eds. K. Lansey, H. Vafai and D. Quanrud (Irvine, California: University of Arizone), 38-45.

Al-Hemaid, F., and Thomas, J. (1996). Review of the genus Tribulus L. @ in Saudi Arabia. Arab Gulf J. Sci. Res. 14, 415-443.

Al-Oudat, M., and Qadir, M. (2011). The Halophytic Flora of Syria (Aleppo, Syria: International Center for Agricultural Research in the Dry Areas). 
Ananda Rao, T., and Meher-Homji, V. M. (1985). Strand plant communities of the Indian sub-continent. Proc. Indian Acad. Sci. (Plant Sci.) 94, 505-523. doi: 10.1007/BF03053163

APG III (The Angiosperm Phylogeny Group) (2009). An update of the Angiosperm Phylogeny Group classification for the orders and families of flowering plants: APG III. Bot. J. Linn. Soc. 161, 105-121. doi: 10.1111/j.1095-8339.2009.00996.x

APG IV (The Angiosperm Phylogeny Group) (2016). An update of the Angiosperm Phylogeny Group classification for the orders and families of flowering plants: APG IV. Bot. J. Linn. Soc. 181, 1-20. doi: 10.1111/boj.12385

Applequist, W. L. (2016). Report of the Nomenclature Committee for Vascular Plants: 68. Taxon 65, 1153-1165. doi: 10.12705/655.16

Arafat, S., Gaafar, A., Basuny, A., and Nassef, S. (2009). Chufa Tubers (Cyperus esculentus L.): As a New Source of Food. World Appl. Sci. J. 7, 151-156.

Assefa, K., Chanyalew, S., and Tadele, Z. (2017). “Tef, Eragrostis tef (Zucc.) Trotter," in Millets and Sorghum: Biology and Genetic Improvement. Ed. J. V. Patil (Chennai: John Wiley and Sons Ltd), 226-256. doi: 10.1002/9781119130765.ch9

Atala, A. (2012). A new ingredient: The introduction of priprioca in gastronomy. Int. J. Gastronomy Food Sci. 1, 61-63. doi: 10.1016/j.ijgfs.2011.11.001

Attorre, F., Francesconi, F., Taleb, N., Scholte, P., Saed, A., Alfo, M., et al. (2007). Will dragonblood survive the next period of climate change? Current and future potential distribution of Dracaena cinnabari (Socotra, Yemen). Biol. Conserv. 138, 430-439. doi: 10.1016/j.biocon.2007.05.009

Batanouny, K., Stichler, W., and Ziegler, H. (1988). Photosynthetic pathways, distribution, and ecological characteristics of grass species in egypt. Oecologia 75, 539-548. doi: 10.1007/BF00776418

Bertea, M., and Maffei, M. (2009). Botany, including anatomy, physiology, biochemistry and molecular biology. Essential Oil-Bearing Grasses: The genus Cymbopogon,. Ed. A. Akhila (London: Taylor and Francis), 1-24. doi: 10.1201/ 9780849378584

Bond, W., Woodward, F., and Midgley, G. (2005). The global distribution of ecosystems in a world without fire. New Phytol. 165, 525-538. doi: 10.1111/ j.1469-8137.2004.01252.x

Boteva, H., Dintcheva, T., Masheva, S., Yankova, V., and Markova, D. (2014). Opportunities for Growing Tribulus terrestris L. as Semi-Culture. Biotechnol. Biotechnol. Equip. 25, 2388-2390. doi: 10.5504/BBEQ.2011.0029

Bräutigam, A., and Gowik, U. (2016). Photorespiration connects $C_{3}$ and $C_{4}$ photosynthesis. J. Exp. Bot. 67, 2953-2962. doi: 10.1093/jxb/erw056

Bräutigam, A., Schliesky, S., Külahoglu, C., Osborne, C., and Weber, A. (2014). Towards an integrative model of $\mathrm{C} 4$ photosynthetic subtypes: insights from comparative transcriptome analysis of NAD-ME, NADP-ME, and PEP-CK C4 species. J. Exp. Bot. 65, 3579-3593. doi: 10.1093/jxb/eru100

Breckle, S., and Rafiqpoor, M. (2010). "Field Guide Afghanistan - Flora and Vegetation. Deutsche Nationalbibliothek," (Bonn: Scientia Bonnensis).

Breckle, S., Hedge, I., and Rafiqpoor, M. (2013). "Vascular Plants of Afghanistan: An Augmented Checklist," in Scientia Bonnensis, Bonn, Manama, New York, Florianapólis.

Brown, G., and Mies, B. (2012). The vegetation ecology of Socotra. (Dordrecht: Springer, Netherland). doi: 10.1007/978-94-007-4141-6

Brullo, C., Brullo, S., Gaskin, J., Galdo, G., Hrusa, G., and Salmeri, C. (2015). A new species of Kali (Salsoloideae, Chenopodiaceae) from Sicily, supported by molecular analysis. Phytotaxa 201, 256-277. doi: 10.11646/phytotaxa.201.4.2

Byrne, M., Pendergrass, A., Rapp, A., and Wodzicki, K. (2018). Response of the Intertropical Convergence Zone to Climate Change: Location, Width, and Strength. Curr. Climate Change Rep. 4, 355-370. doi: 10.1007/s40641-018-0110-5

CABI Invasive Species Compendium (Wallingford, UK: CAB International). Available at: https://www.cabi.org/ISC/ (Accessed Accessed: 14.01.2020).

Cabido, M., Pons, E., Cantero, J., Lewis, J., and Anton, A. (2008). Photosynthetic pathway variation among $\mathrm{C}_{4}$ grasses along a precipitation gradient in Argentina. J. Biogeogr. 35, 131-140. doi: 10.1111/j.1365-2699.2007.01760.x

Centofanti, T., and Bañuelos, G. (2015). Evaluation of the halophyte Salsola soda as an alternative crop for saline soils high in selenium and boron. J. Environ. Manage. 157, 96-102. doi: 10.1016/j.jenvman.2015.04.005

Chandran, M. (2015). Grassland vegetation of India: An update. Ecology and Management of Grassland Ecology in India -. Envis Bull. 17. Wildlife Institute of India, Dehradun.

Chaudhri, I. I., Hussain, S. I., and Shah, B. H. (1966). The vegetation of riverian tract of the Indus around Ghulam Mohammed Barrage, West Pakistan. Vegetatio 13, 319-338. doi: 10.1007/BF00242772
Cheikhyoussef, A., Mapaure, I., and Shapi, M. (2011). The use of some Indigenous Plants for Medicinal and other Purposes by Local Communities in Namibia with Emphasis on Oshikoto Region: A Review. Res. J. Med. Plant 5, 406-419. doi: 10.3923/rjmp.2011.406.419

Christin, P., Besnard, G., Samaritani, E., Duvall, M., Hodkinson, T., Savolainen, V., et al. (2008). Oligocene $\mathrm{CO}_{2}$ Decline Promoted $\mathrm{C}_{4}$ Photosynthesis in Grasses. Curr. Biol. 18, 37-43. doi: 10.1016/j.cub.2007.11.058

Chuong, S. D. X., Franceschi, V. R., and Edwards, G. E. (2006). The cytoskeleton maintains organelle partitioning required for single-cell $\mathrm{C}_{4}$ photosynthesis in Chenopodiaceae species. Plant Cell 18, 2207-2223. doi: 10.1105/tpc.105.036186

Danin, A., and Orshan, G. (1999). Vegetation of Israel I. Desert and coastal vegetation. (Leiden: Backuys Publishers).

Danin, A. (2007). "Edible Leaves and Fruits," in Plant Stories. Available at: https:// flora.org.il/en/books/plant-stories-2/.

Dasti, A., and Agnew, A. D. Q. (1994). The vegetation of Cholistan and Thal deserts, Pakistan. J. Arid Environ. 27, 193-208. doi: 10.1006/jare.1994.1058

Davis, P. (1966-2001). Flora of Turkey and the East Aegean Islands (Edinburgh: Edinburgh University Press).

Deil, U., and Müller-Hohenstein, K. (1985). Beiträge zur Vegetation des Jemen I Pflanzengesellschaften und Ökotopgefüge der Gebirgstihamah am Beispiel des Beckens von At Tur (J.A.R.). Phytocoenologia 13, 1-102. doi: 10.1127/phyto/ 13/1985/1

Diez-Garretas, B., and Asensi, A. (1999). Syntaxonomic analysis of the andropogon-rich grasslands (Hyparrhenietalia hirtae) in the western mediterranean region. Folia Geobot. 34, 307-320. doi: 10.1007/BF02912817

Djamali, M., Akhani, H., Andrieu-Ponel, V., Bracconnot, P., Brewer, S., de Beaulieu, J.-L., et al. (2010). Indian Summer Monsoon variations could have affected the early Holocene woodland expansion in the Near East. Holocene 20, 813-820. doi: $10.1177 / 0959683610362813$

Djamali, M., Akhani, H., Khoshravesh, R., Andrieu-Ponel, V., Ponel, P., and Brewer, S. (2011). Application of the Global Bioclimatic Classification to Iran: implications for understanding the modern vegetation and biogeography. Int. J. Mediterranean Ecol. 37, 91-114. doi: 10.3406/ ecmed.2011.1350

Djamali, M., Brewer, S., Breckle, S., and Jackson, S. (2012). Climatic determinism in phytogeographic regionalization: A test from the Irano-Turanian region, SW and Central Asia. Flora - Morphol. Distribution Funct. Ecol. Plant 207, 237-249. doi: 10.1016/j.flora.2012.01.009

Doostmohammadi, M., Malekmohammadi, M., Djamali, M., and Akhani, H. (2020). Is Pteropyrum a pathway to $\mathrm{C}_{4}$ evolution in Polygonaceae? An integrative approach to the taxonomy and anatomy of Pteropyrum $\left(\mathrm{C}_{3}\right)$, an immediate relative to Calligonum $\left(\mathrm{C}_{4}\right)$. Bot. J. Linn. Soc. 192, 369-400. doi: 10.1093/botlinnean/boz079

Duke, J. (1993). CRC handbook of alternative cash crops (CRC Press).

Dzyubenko, N., and Soskov, Y. (2014). Geneticheskie resursy Kokhii prostyortoy Kochia prostrata (L.) Schrad (Sankt-Petersburg: SPB:VIR).

Edwards, G., Franceschi, V., and Voznesenskaya, E. (2004). Single-Cell $\mathrm{C}_{4}$ Photosynthesis Versus the Dual-Cell (kranz) Paradigm. Annu. Rev. Plant Biol. 55, 173-196. doi: 10.1146/annurev.arplant.55.031903.141725

Ehleringer, J., Lin, Z., Field, C., Sun, G., and Kuo, C. (1987). Leaf carbon isotope ratios of plants from a subtropical monsoon forest. Oecologia 72, 109-114. doi: $10.1007 / \mathrm{BF} 00385053$

El-Ghanim, W. M., Hassanb, L. M., Galal, L. M., and Badr, A. (2010). Floristic composition and vegetation analysis in Hail region north of central Saudi Arabia. Saudi J. Biol. Sci. 17, 119-128. doi: 10.1016/j.sjbs.2010.02.004

El-Kamali, H., Hamza, M., and El-Amir, M. (2005). Antibacterial activity of the essential oil from Cymbopogon nervatus inflorescence. Fitoterapia 76, 446449. doi: 10.1016/j.fitote.2005.03.001

Elmore, C., and Paul, R. (1983). Composite List of $C_{4}$ Weeds. Weed Sci. 31, 686692. doi: $10.1017 /$ S0043174500070193

El-Sheikh, M. A. (2013). Weed vegetation ecology of arable land in Salalah, Southern Oman. Saudi J. Biol. Sci. 20, 291-304. doi: 10.1016/j.sjbs.2013.03.001

Evans, J. (2009). 21st century climate change in the Middle East. Clim. Change 92, 417-432. doi: 10.1007/s10584-008-9438-5

Fayvush, G. M., and Aleksanyan, A. S. (2016). Habitats of Armenia. Bot. Institute Yerevan. doi: 10.13140/RG.2.1.1695.9601

Fern, K. (2016). Useful Temperate Plants Database. Available at: http://temperate. theferns.info/ (Accessed 22.06.2019). 
Fet, V., and Atamuradov, K. (1994). Biogeography and Ecology of Turkmenistan (Dordrecht: Springer). doi: 10.1007/978-94-011-1116-4

Freitag, H., and Stichler, W. (2000). A Remarkable New Leaf Type With Unusual Photosynthetic Tissue in a Central Asiatic Genus of Chenopodiaceae. Plant Biol. 2, 154-160. doi: 10.1055/s-2000-9462

GBC (Worldwide Bioclimatic Classification System). Available at: http://www. globalbioclimatics.org/ (Accessed 13.06.2019).

Ghasemkhani, M., Akhani, H., Sahebi, J., and Scholz, H. (2008). The genera Aristida and Stipagrostis (Poaceae) in Iran. Willdenowia 38, 135-148. doi: $10.3372 /$ wi.38.38108

Ghazanfar, S. A., and Fisher, M. (1998). Vegetation of the Arabian Peninsula (Dordrecht: Springer). doi: 10.1007/978-94-017-3637-4

Ghorbanalizadeh, A., Akhani, H., and Bergmeier, E. (2020). Vegetation patterns of a rapidly drying up salt lake ecosystem: Lake Urmia, NW Iran. Phytocenologia 50, 1-46. doi: 10.1127/phyto/2019/0338

Gintzburger, G., Toderich, K., Mardonov, B., and Mahmudov, M. (2003). Rangelands of the Arid and Semi-Arid zones in Uzbekistan. ClRAD ICARDA.

Gomashe, S. (2017). "Proso Millet, Panicum miliaceum (L.): Genetic Improvement and Research Needs," in Millets and Sorghum: Biology and Genetic Improvement. Ed. J. V. Patil (Chennai: John Wiley and Sons Ltd), 150169. doi: 10.1002/9781119130765.ch5

Gonnella, M., Charfeddine, M., Conversa, G., and Santamaria, P. (2010). Purslane: A Review of its Potential for Health and Agricultural Aspects. Eur. J. Plant Sci. Biotechnol. 4, 131-136.

Guest, E., and Ghazanfar, S. (1966-2013). "Flora of Iraq," vols. 1-9, (Kew: Royal Botanic Gardens, Bentham-Moxon Trust).

Gutermann, W. (2011). Notulae nomenclaturales 41-45. Phyton-Annales Rei Botanicae 51, 95-102.

Haghshenas-Haghighi, M., and Motagh, M. (2019). Ground surface response to continuous compaction of aquifer system in Tehran, Iran: Results from a longterm multi-sensor InSAR analysis. Remote Sens. Environ. 221, 534-550. doi: 10.1016/j.rse.2018.11.003

Hakobyan, J. (2011). The genus Salsola sensu lato (Chenopodiaceae) in southern Transcaucasia. Takhtajania 1, 124-132.

Han, L., Nose, R., Li, W., Gong, X., Zheng, Y., Yoshikawa, M., et al. (2006). Reduction of fat storage in mice fed a high-fat diet long term by treatment with saponins prepared from Kochia scoparia fruit. Phytother. Res. 20, 877-882. doi: $10.1002 /$ ptr. 1981

Hanelt, P. (2001). Mansfeld's Encyclopedia of Agricultural and Horticultural Crops. (Springer Verlag Berlin Heidelberg).

Hariprasanna, K. (2017). "Foxtail Millet, Setaria italica (L.) P. Beauv," in Millets and Sorghum - Wiley Online Library. Millets and Sorghum: Biology and Genetic Improvement. Ed. J. V. Patil (Chennai: John Wiley and Sons Ltd), 112-149. doi: 10.1002/9781119130765.ch4

Hatch, M. D. (1999). "C4 photosynthesis: A historical overview," in C4 Plant Biology. Eds. R. Sage and R. Monson (San Diego, California: Academic Press), $17-46$.

Hattersley, P. (1983). The distribution of $\mathrm{C}_{3}$ and $\mathrm{C}_{4}$ grasses in Australia in relation to climate. Oecologia 57, 113-128. doi: 10.1007/BF00379569

Hernandez-Ledesma, P., Berendsohn, W., Borsch, T., Von Mering, S., Akhani, H., Arias, S., et al. (2015). A taxonomic backbone for the global synthesis of species diversity in the angiosperm order Caryophyllales. Willdenowia 45, 281-384. doi: 10.3372/wi.45.45301

Hodkinson, T. R., Chase, M. W., Lledo, D. M., Salamin, N., and Renvoize, S. A. (2002). Phylogenetics of Miscanthus, Saccharum and related genera (Saccharinae, Andropogoneae, Poaceae) based on DNA sequences from ITS nuclear ribosomal DNA and plastid trnL intron and trnL-F intergenic spacers. J. Plant Res. 115, 381-392. doi: 10.1007/s10265-002-0049-3

Hoetzel, S., Dupont, L., Schefuß, E., Rommerskirchen, F., and Wefer, G. (2013). The role of fire in Miocene to Pliocene $\mathrm{C}_{4}$ grassland and ecosystem evolution. Nat. Geosci. 6, 1027-1030. doi: 10.1038/ngeo1984

Ingram, A. L., and Doyle, J. J. (2003). The origin and evolution of Eragrostis tef (Poaceae) and related polyploids: evidence from nuclear waxy and plastid rps16. Am. J. Bot. 90, 116-122. doi: 10.3732/ajb.90.1.116

IPNI (2019). International Plant Names Index (The Royal Botanic Gardens, Kew, Harvard University Herbaria \& Libraries and Australian National Botanic Gardens). Available at: http://www.ipni.org.
IRIMO Data Base of Iranian Meteorological Organization. Available at: http:// data.irimo.ir (Accessed 12.12.2018).

James, G. (2014). "An Introduction to Sugarcane," in Sugarcane (Oxford: Blackwell Publishing Ltd), 1-19.

Jana, K., and Puste, A. (2014). Madur Kathi - An Important Economic Non-food Crop of West Bengal. Asian Agri-History 18, 145-151.

Kadereit, G., and Freitag, H. (2011). Molecular phylogeny of Camphorosmeae (Camphorosmoideae, Chenopodiaceae): Implications for biogeography, evolution of C4-photosynthesis and taxonomy. Taxon 60, 51-78. doi: $10.1002 / \operatorname{tax} .601006$

Kadereit, G., Borsch, T., Weising, K., and Freitag, H. (2003). Phylogeny of Amaranthaceae and Chenopodiaceae and the Evolution of $\mathrm{C}_{4}$ Photosynthesis. Int. J. Plant Sci. 164, 959-986. doi: 10.1086/378649

Kadereit, G., Ackerly, D., and Pirie, M. (2012). A broader model for $\mathrm{C}_{4}$ photosynthesis evolution in plants inferred from the goosefoot family (Chenopodiaceae s.s.). Proc. R. Soc. B.: Biol. Sci. 279, 3304-3311. doi: $10.1098 / \mathrm{rspb} .2012 .0440$

Kapralov, M. V., Akhani, H., Voznesenskaya, E. V., Edwards, G., Franceschi, V., and Roalson, E. H. (2006). Phylogenetic relationships in the Salicornioideae/ Suaedoideae/Salsoloideae s.l. (Chenopodiaceae) Clade and a clarification of the phylogenetic position of Bienertia and Alexandra using multiple DNA sequence datasets. Syst. Bot. 31, 571-585. doi: 10.1600/036364406778388674

Keeley, J. E., and Rundel, P. (2005). Fire and the Miocene expansion of $\mathrm{C}_{4}$ grasslands. Ecol. Lett. 8, 683-690. doi: 10.1111/j.1461-0248.2005.00767.x

Kellogg, E. A. (2015). The Families and Genera of Vascular Plants - Flowering Plants (Monocots. Poaceae: Springer, Cham). doi: 10.1007/978-3-319-15332-2

Khyade, V., Pawar, S., and Sarwade, J. (2018). Novel Sacrificial Medicinal Repositories: Halfa grass, Desmostachya bipinnata (L.) and Cogon grass, Imperata cylindrica (L.). World Sci. News 100, 35-50.

Kool, A. (2012). Desert Plants and Deserted Islands: Systematics and Ethnobotany in Caryophyllaceae (Uppsala: Acta Universitatis Upsaliensis).

Kripa, K., and Vijayalakshmi, S. (2016). Therapeutic uses of plants of genus Blepharis - a systematic review. Int. J. Pharma Bio Sci. 7, 236-243. doi: 10.22376/ijpbs.2016.7.4.b236-243

Kürschner, H. (1986). Contributions to the Vegetation of Southwest Asia. Tübinger Atlas des Vorderen Orients (TAVO) 24 (Tübingen: Reichert Verlag).

Lauterbach, M., Billakurthi, K., Kadereit, G., Ludwig, M., Westhoff, P., and Gowik, U. (2017). $C_{3}$ cotyledons are followed by $C_{4}$ leaves: intra-individual transcriptome analysis of Salsola soda (Chenopodiaceae). J. Exp. Bot. 68, 161-176. doi: 10.1093/jxb/erw343

Léonard, J. (1988). Contribution a l'etude de la Flore et de la Vegetation des Deserts d'Iran (Dasht-E-Kavir, Dasht-E-Lut, Jaz Murian). Fasc. 8: Etude des aires de distribution, Les phytochories, Les chorotypes. (Meise: Jardin botanique Natl. Belgique).

Li, Y., Feng, Y., Wang, X., Liu, B., and Lv, G. (2014). Failure of DNA barcoding in discriminating Calligonum species. Nordic J. Bot. 32, 511-517. doi: 10.1111/njb.00423

Li, Y., Ma, X., Zhao, J., Xu, J., Shi, J., Zhu, X., et al. (2015). Developmental Genetic Mechanisms of $\mathrm{C} 4$ Syndrome Based on Transcriptome Analysis of $\mathrm{C}_{3}$ Cotyledons and $\mathrm{C}_{4}$ Assimilating Shoots in Haloxylon ammodendron. PloS One 10, e0117175. doi: 10.1371/journal.pone.0117175

Madani, K. (2014). Water management in Iran: what is causing the looming crisis? J. Environ. Stud. Sci. 4, 315-328. doi: 10.1007/s13412-014-0182-z

Mahesh, A., Kumar, H., Ranganath, M., and Devkar, R. (2012). Detail Study on Boerhaavia Diffusa Plant for its Medicinal Importance-A Review. Res. J. Pharm. Sci. 1, 28-36.

Mantlana, K., Arneth, A., Veenendaal, E., Wohland, P., Wolski, P., Kolle, O., et al. (2008). Photosynthetic properties of $\mathrm{C}_{4}$ plants growing in an African savanna/ wetland mosaic. J. Exp. Bot. 59, 3941-3952. doi: 10.1093/jxb/ern237

Medina, E., Cram, W., Lee, H., Luettge, U., Popp, M., Smith, J., et al. (1989). Ecophysiology of xerophytic and halophytic vegetation of a coastal alluvial plain in northern Venezuela. New Phytol. 111, 233-243. doi: 10.1111/j.14698137.1989.tb00688.x

Miller, A., and Cope, T. (1996). Flora of the Arabian Peninsula and Socotra (Edinburgh: Edinburgh University Press).

Mosyakin, S. L., Rilke, S., and Freitag, H. (2014). Proposal to conserve the name Salsola (Chenopodiaceae s.str.; Amaranthaceae sensu APG) with a conserved type. Taxon 63, 1134-1135. doi: 10.12705/635.15 
Mosyakin, S. L., Freitag, H., and Rilke, S. (2017). Kali versus Salsola: the instructive story of a questionable nomenclatural resurrection. Israel J. Plant Sci. 64, 1830. doi: 10.1080/07929978.2016.1256135

Motagh, M., Walter, T. R., Sharifi, M. A., Fielding, E., Schenk, A., Anderssohn, J., et al. (2008). Land subsidence in Iran caused by widespread water reservoir overexploitation. Geophys. Res. Lett. 35. doi: 10.1029/2008GL033814

Motagh, M., Shamshiri, R., Haghshenas-Haghighi, M., Wetzel, H. U., Akbari, B., Nahavandchi, H., et al. (2017). Quantifying groundwater exploitation induced subsidence in the Rafsanjan plain, southeastern Iran, using InSAR time-series and in situ measurements. Eng. Geol. 218, 134-151. doi: 10.1016/ j.enggeo.2017.01.011

Mucina, L., Bültmann, H., Dierßen, K., Theurillat, J. P., Raus, T., Čarni, A., et al. (2016). Vegetation of europe: Hierarchical floristic classification system of vascular plant, bryophyte, lichen, and algal communities. App. Veg. Sci. 19, 3264. doi: 10.1111/avsc.12257

Mullet, J. (2017). High-biomass $\mathrm{C}_{4}$ grasses-Filling the yield gap. Plant Sci.: Int. J. Exp. Plant Biol. 261, 10-17. doi: 10.1016/j.plantsci.2017.05.003

Nasir, E., and Ali, S. I. (1970-2003). Edit. Flora of Pakistan (Karachi: University of Karachi), 1-202.

Nechayeva, N. T. (1992). Rastitelnost Turkmenistana (Ashgabat, Ylym).

Nedelcheva, A., Dogan, Y., and Guarrera, P. (2007). Plants traditionally used to make brooms in several European countries. J. Ethnobiol. Ethnomed. 3, 20. doi: 10.1186/1746-4269-3-20

Nikitin, V., and Geldikhanov, A. (1988). Opredelitel rastenij Turkmenistana (Ashgabat: Academy of sciences of the Turkmen SSR).

Origin Pro, Version Number (2017). OriginLab Corporation (Northampton, MA, USA).

O’Leary, M. (1988). Carbon Isotopes in Photosynthesis. BioScience 38, 328-336. doi: $10.2307 / 1310735$

Osborne, C., and Beerling, D. (2006). Nature's green revolution: the remarkable evolutionary rise of $\mathrm{C}_{4}$ plants. Philos. Trans. R. Soc. London. Ser. B. Biol. Sci. 361, 173-194. doi: 10.1098/rstb.2005.1737

Osborne, C. (2010). "The Geologic History of C4 Plants. Advances in Photosynthesis and Respiration," in C4 Photosynthesis and Related CO2 Concentrating Mechanisms (Dordrecht: Springer), 339-357. doi: 10.1007/ 978-90-481-9407-0

Osmond, C., Ziegler, H., Stichler, W., and Trimborn, P. (1975). Carbon isotope discrimination in alpine succulent plants supposed to be capable of Crassulacean acid metabolism (CAM). Oecologia 28, 323-328. doi: 10.1007/BF00345423

Pahlevani, A. H., Liede-Schumann, S., and Akhani, H. (2020). Diversity, distribution, endemism and conservation status of Euphorbia (Euphorbiaceae) in SW Asia and adjacent countries. Plant Syst. Evol. 306, 80. doi: 10.1007/ s00606-020-01705-4

Pal, J. S., and Eltahir, E. A. B. (2016). Future temperature in southwest Asia projected to exceed a threshold for human adaptability. Nat. Climate Change 6, 197-200. doi: 10.1038/nclimate2833

Pareek, A., and Kumar, A. (2013). Ethnobotanical and pharmaceutical uses of Vetiveria zizanioides (Linn) Nash: a medicinal plant of Rajasthan. Int. J. Life Sci. Pharma Res. 3, L12-118.

Pascual, B., Maroto, J., Lopez-Galarza, S., and Sanbautista, A. (2000). Chufa (Cyperus esculentus L. var. sativus Boeck.): Unconventional crop. Studies related to applications and cultivation. Economic Bot. 54, 439-448. doi: 10.1007/BF02866543

Pérez-García, F., Akhani, H., Parsons, R., Silcock, J. L., Kurt, L., Özdeniz, E., et al. (2018). A first inventory of gypsum flora in the Palearctic and Australia. Mediterranean Bot. 39, 35-49. doi: 10.5209/MBOT.59428

POWO (2019). "Plants of the World Online (Facilitated by the Royal Botanic Gardens, Kew). Available at: http://www.plantsoftheworldonline.org/.

Prasad, C., Singh, D., Shkula, O., and Singh, U. (2014). Cymbopogon jwarancusa An important medicinal plant: A review. Pharma Innovation J. 3, 13-19.

PROTA4U web database (2018). Available at: https://www.prota4u.org/database/ (Accessed 23.06.2019).

Pyankov, V., Black, C., Artyusheva, E., Voznesenskaya, E., Ku, M., and Edwards, G. (1999). Features of Photosynthesis in Haloxylon species of Chenopodiaceae that are Dominant Plants in Central Asian Deserts. Plant Cell Physiol. 40, 125134. doi: 10.1093/oxfordjournals.pcp.a029519

Pyankov, V., Gunin, P., Tsoog, S., and Black, C. (2000a). C 4 plants in the vegetation of Mongolia: their natural occurrence and geographical distribution in relation to climate. Oecologia 123, 15-31. doi: 10.1007/ s004420050985

Pyankov, V., Voznesenskaya, E., Kuz'min, A., Ku, M., Ganko, E., Franceschi, V., et al. (2000b). Occurrence of $\mathrm{C}_{3}$ and $\mathrm{C}_{4}$ photosynthesis in cotyledons and leaves of Salsola species (Chenopodiaceae). Photosynth. Res. 63, 69-84. doi: 10.1023/ A:1006377708156

Pyankov, V., Ziegler, H., Kuz'min, A., and Edwards, G. (2001). Origin and evolution of $\mathrm{C}_{4}$ photosynthesis in the tribe Salsoleae (Chenopodiaceae) based on anatomical and biochemical types in leaves and cotyledons. Plant Syst. Evol. 230, 43-74. doi: 10.1007/s006060170004

Pyankov, V., Ziegler, H., Akhani, H., Deigele, C., and Lüttge, U. (2010). European plants with $\mathrm{C}_{4}$ photosynthesis: geographical and taxonomic distribution and relations to climate parameters. Bot. J. Linn. Soc. 163, 283-304. doi: 10.1111/ j.1095-8339.2010.01062.x

Raghavendra, A., and Das, V. (1976). Distribution of the $\mathrm{C}_{4}$ dicarboxylic acid pathway of photosynthesis in local Monocotyledonous plants and its taxonomic significance. New Phytol. 76, 301-305. doi: 10.1111/j.1469-8137.1976.tb01465.x

Rao, X., and Dixon, R. (2016). The Differences between NAD-ME and NADP-ME Subtypes of $\mathrm{C}_{4}$ Photosynthesis: More than Decarboxylating Enzymes. Front. Plant Sci. 7, 1525. doi: 10.3389/fpls.2016.01525

Ravichandran, P., Thumilan, M., Benazir, J., and Manimekalai, V. (2005). Anatomy and Vascular Bundle Diversity in Mat sedges. Phytomorphology 55, 75-83.

Raza, M., Hussain, D., Rasul, G., Akbar, M., and Raza, G. (2015). Variations of surface temperature and precipitation in Gilgit-Baltistan (GB), Pakistan from 1955 to 2010. J. Biodivers. Environ. Sci. 6, 67-73.

Rechinger, K. H. (1963-2015). Flora Iranica: Flora des iranischen Hochlandes und der umrahmenden Gebirge, , Fas. 1-181 (Graz, Austria: Akademische Druck - u. Verlagsanstalt).

Rejzek, M., Svatek, M., Sebesta, J., Adolt, R., Madera, P., and Matula, R. (2016). Loss of a single tree species will lead to an overall decline in plant diversity: Effect of Dracaena cinnabari Balf. f. on the vegetation of Socotra Island. Biol. Conserv. 196, 165-172. doi: 10.1016/j.biocon.2016.02.016

Rivas-Martinez, S., and Rivas-Saenz, S. (1996-2019). Worldwide Bioclimatic Classification System Phytosociological Research Center. Available at: https:// www.globalbioclimatics.org/

Rodwell, M., and Hoskins, B. J. (1996). Monsoons and the dynamics of deserts. Quartly J. R. Meteorol. Soc. 122, 1385-1404. doi: 10.1002/qj.49712253408

Rukhlenko, I. A. (2001). The order Aeluropodetalia littoralis in the flood plain of Atrek River (South West Turkmenia). Feddes Repertorium 112, 107-125. doi: $10.1002 /$ fedr.20011120116

Rundel, P., Esler, K., and Cowling, R. (1999). Ecological and phylogenetic patterns of carbon isotope discrimination in the winter-rainfall flora of the Richtersveld, South Africa. Plant Ecol. 142, 133-148. doi: 10.1023/A:1009878429455

Sage, R., and Sultmanis, S. (2016). Why Are There No C 4 Forests? J. Plant Physiol. 203, 55-68. doi: 10.1016/j.jplph.2016.06.009

Sage, R., Sage, T., and Kocacinar, F. (2012). Photorespiration and the evolution of $\mathrm{C}_{4}$ photosynthesis. Annu. Rev. Plant Biol. 63, 19-47. doi: 10.1146/annurevarplant-042811-105511

Sage, R. (2001). Environmental and Evolutionary Preconditions for the Origin and Diversification of the $\mathrm{C}_{4}$ Photosynthetic Syndrome. Plant Biol. 3, 202-213. doi: $10.1055 / \mathrm{s}-2001-15206$

Sage, R. (2004). The evolution of C4 photosynthesis. New Phytol. 161, 341-370. doi: 10.1111/j.1469-8137.2004.00974.x

Sage, R. (2011). The $\mathrm{C}_{4}$ plant lineages of planet Earth. J. Exp. Bot. 62, 3155-3169. doi: $10.1093 / \mathrm{jxb} / \mathrm{err} 048$

Sage, R. (2016). A portrait of the $\mathrm{C}_{4}$ photosynthetic family on the 50th anniversary of its discovery: species number, evolutionary lineages, and Hall of Fame. J. Exp. Bot. 67, 4039-4056. doi: 10.1093/jxb/erw156

Sahu, S., Rout, N., and Dhal, N. (2010). Ethnobotany of Eulaliopsis binata (Retz.) Hubbard- Poaceae, in Odisha, Eastern India: Cultivation Practice, Economics and Prospects. J. Adv. Dev. Res. 1, 155-160.

Salamon, I., Grulova, D., and De Feo, V. (2016). Comparison of two methods for field grow of puncture vine (Tribulus terrestris L.) in Slovakia. Acta Agric. Scand. Sect. B. - Soil Plant Sci. 66, 267-271. doi: 10.1080/09064710.2015.1093652

Sanjana Reddy, P. (2017a). "Sorghum, Sorghum bicolor (L.) Moench. Millets and Sorghum - Wiley Online Library," in Millets and Sorghum: Biology and Genetic Improvement. Ed. J. V. Patil (Chennai: John Wiley and Sons Ltd), 1-48. doi: 10.1002/9781119130765.ch1 
Sanjana Reddy, P. (2017b). "Pearl Millet, Pennisetum glaucum (L.) R. Br," in Millets and Sorghum: Biology and Genetic Improvement Editor. Ed. J. V. Patil (Chennai: John Wiley and Sons Ltd), 49-86. doi: 10.1002/9781119130765.ch2

Sauer, J. (1967). The grain amaranths and their relatives: a revised taxonomic and geographic survey. Ann. Missouri Bot. Garden 54, 103-137. doi: 10.2307/ 2394998

Scholte, P., and De Geest, P. (2010). The climate of Socotra Island (Yemen): A first-time assessment of the timing of the monsoon wind reversal and its influence on precipitation and vegetation patterns. J. Arid Environ. 74, 15071515. doi: 10.1016/j.jaridenv.2010.05.017

Schuler, M. L., Mantegazza, O., and Weber, A. P. (2016). Engineering $C_{4}$ photosynthesis into $\mathrm{C}_{3}$ chassis in the synthetic biology age. Plant J. 87, 5165. doi: $10.1111 /$ tpj. 13155

Schulze, E., Ellis, R., Schulze, W., Trimborn, P., and Ziegler, H. (1996). Diversity, metabolic types and $\delta^{13} \mathrm{C}$ carbon isotope ratios in the grass flora of Namibia in relation to growth form, precipitation and habitat conditions. Oecologia 106, 352-369. doi: 10.1007/BF00334563

Schüssler, C., Freitag, H., Koteyeva, N., Schmidt, D., Edwards, G., Voznesenskaya, E., et al. (2017). Molecular phylogeny and forms of photosynthesis in tribe Salsoleae (Chenopodiaceae). J. Exp. Bot. 68, 207-223. doi: 10.1093/jxb/erw432

Seetharam, A., and Riley, K. (1986). "Small Millets in Global Agriculture," in Proceedings of the First International Small Millets Workshop, October 29November 2, 1986 (Bangalore, India: Oxford and IBH Publishing Company).

Serag, M. (2003). Ecology and biomass production of Cyperus papyrus L. on the Nile bank at Damietta, Egypt. J. Mediterranean Ecol. 4, 15-24.

Shi, W., Wen, J., and Pan, B. (2016). A comparison of ITS sequence data and morphology for Calligonum pumilum and C. mongolicum (Polygonaceae) and its taxonomic implications. Phytotaxa 261, 157-167. doi: 10.11646/phytotaxa.261.2.5

Shioya, M., Myoga, A., Kitagawa, A., Tokunaga, Y., Hayashi, H., Kogo, Y., et al. (2019). Analysis of deflection and dynamic plant characteristics of Cyperus malaccensis Lam. Plant Prod. Sci. 22, 1-8. doi: 10.1080/1343943X.2019.1588075

Shmida, A., and Aronson, J. A. (1986). Sudanian Elements in the Flora of Israel. Ann. Missouri Bot. Garden 73, 1-28. doi: 10.2307/2399138

Simpson, D., and Inglis, C. (2001). Cyperaceae of Economic, Ethnobotanical and Horticultural Importance: A Checklist. Kew Bull. 56, 257-360. doi: 10.2307/4110962

Skinner, R. H., Hanson, J. D., Hutchinson, G. L., and Schuman, G. E. (2002). Response of $\mathrm{C}_{3}$ and $\mathrm{C}_{4}$ grasses to supplemental summer precipitation. J. Range Manage. 55, 517-522. doi: 10.2458/azu_jrm_v55i5_skinner

Snead, R. E., and Tasnif, M. (1966). Vegetation Types in the Las Bela Region of West Pakistan. Ecology 47, 494-499. doi: 10.2307/1932993

Soreng, R. J., Peterson, P. M., Romaschenko, K., Davidse, G., Zuloaga, F. O., Judziewicz, E. J., et al. (2015). A worldwide phylogenetic classification of the Poaceae (Gramineae). J. Syst. Evol. 53, 117-137. doi: 10.1111/jse.12262

Soreng, R. J., Peterson, P. M., Romaschenko, K., Davidse, G., Teisher, J. K., Clark, L. G., et al. (2017). A worldwide phylogenetic classification of the Poaceae (Gramineae) II: An update and a comparison of two 2015 classifications. J. Syst. Evol. 55, 259-290. doi: 10.1111/jse.12262

Soskov, Y. (2011). Rod Calligonum L. - zhuzgun (sistematika, geografiya, evolyutsiya, introduktsiya) [Genus Calligonum L. - zhuzgun (taxonomy, geography, evolution, introduction) (Novosibirsk: Siberian Sci. Agric. Library).

Staller, J. (2010). Maize Cobs and Cultures: History of Zea mays L (Berlin Heidelberg: Springer-Verlag), 262. doi: 10.1007/978-3-642-04506-6

Stock, W., Chuba, D., and Verboom, G. (2004). Distribution of South African $\mathrm{C}_{3}$ and $\mathrm{C}_{4}$ species of Cyperaceae in relation to climate and phylogeny. Austral Ecol. 29, 313-319. doi: 10.1111/j.1442-9993.2004.01368.x

Stowe, L., and Teeri, J. (1978). The Geographic Distribution of $\mathrm{C}_{4}$ Species of the Eudicotyledonae in Relation to Climate. Am. Nat. 112, 609-623. doi: 10.1086/ 283301

Sukhorukov, A. P., Liu, P. L., and Kushunina, M. (2019). Taxonomic revision of Chenopodiaceae in Himalaya and Tibet. PhytoKeys 116, 1-141. doi: 10.3897/ phytokeys.116.27301

Suttie, J. M., and Reynolds, S. G. (2003). Transhumant Grazing Systems in Temperate Asia. FAO Plant Prod. Prot. Ser. 31.

Takhtajian, A. (1992). Floristic Regions of the World (Berkeley: University of California Press).

Tavakkoli, S., Kazempour Osaloo, S., and Maassoumi, A. (2010). The Phylogeny of Calligonum and Pteropyrum (Polygonaceae) Based on Nuclear Ribosomal DNA ITS and Chloroplast trnL-F Sequences. Iranian J. Biotechnol. 8, 7-15.
Teeri, J., and Stowe, L. (1976). Climatic patterns and the distribution of $\mathrm{C}_{4}$ grasses in North America. Oecologia 23, 1-12. doi: 10.1007/BF00351210

Tieszen, L., Senyimba, M., Imbamba, S., and Troughton, J. (1979). The distribution of $\mathrm{C}_{3}$ and $\mathrm{C}_{4}$ grasses and carbon isotope discrimination along an altitudinal and moisture gradient in Kenya. Oecologia 37, 337-350. doi: 10.1007/BF00347910

Toderich, K., Black, C. C., Juylova, E., Kozan, O., Mukimov, T., and Matsuo, N. (2007). C3/C4 plants in the vegetation of Central Asia, geographical distribution and environmental adaptation in relation to climate. Climate Change and Terrestrial Carbon Sequestration in Central Asia. (London: CRC Press), 33-63. doi: 10.1201/9780203932698.ch3

Tubeileh, A., Rennie, T., and Goss, M. (2016). A review on biomass production from $\mathrm{C}_{4}$ grasses: yield and quality for end-use. Curr. Opin. Plant Biol. 31, 172180. doi: 10.1016/j.pbi.2016.05.001

Turland, N. J., Wiersema, J. H., Barrie, F. R., Greuter, W., Hawksworth, D. L., Herendeen, P. S., et al. (2018). (Eds) International Code of Nomenclature for algae, fungi, and plants (Shenzhen Code) adopted by the Nineteenth International Botanical Congress Shenzhen, China, July 2017 (Glashütten: Koeltz Botanical Books (Regnum Vegetabile 159).

Uddin, M., Juraimi, A., Hossain, M., Nahar, M., Ali, M., and Rahman, M. (2014). Purslane Weed (Portulaca oleracea): A Prospective Plant Source of Nutrition, Omega-3 Fatty Acid, and Antioxidant Attributes. Sci. World J. doi: 10.1155/2014/951019

Vaezi, A., Ghazban, F., Tavakoli, V., Routh, J., Naderi Beni, A., Bianchi, T. S., et al. (2019). A late Pleistocene-Holocene multi-proxy record of climate variability in the Jazmurian playa, southeastern Iran. Palaeogeogr. Palaeoclimatol. Palaeoecol. 514, 754-767. doi: 10.1016/j.palaeo.2018.09.026

Varghese, M., Yadav, S., and Thomas, J. (2006). Taxonomic Status of Some of the Tribulus Species in the Indian Subcontinent. Saudi J. Biol. Sci. 3, 7-12.

Von Caemmerer, S., Ghannoum, O., Pengelly, J. J. L., and Cousins, A. B. (2014). Carbon isotope discrimination as a tool to explore $\mathrm{C}_{4}$ photosynthesis. J. Exp. Bot. 65, 3459-3470. doi: 10.1093/jxb/eru127

Voznesenskaya, E., Franceschi, V., Kiirats, O., Freitag, H., and Edwards, G. (2001). $\mathrm{Kranz}$ anatomy is not essential for terrestrial $\mathrm{C}_{4}$ plant photosynthesis. Nature 414, 543-546. doi: 10.1038/35107073

Voznesenskaya, E., Franceschi, V., Kiirats, O., Artyusheva, E., Freitag, H., and Edwards, G. (2002). Proof of $\mathrm{C}_{4}$ photosynthesis without Kranz anatomy in Bienertia cycloptera (Chenopodiaceae). Plant J.: For Cell Mol. Biol. 31, 649-662. doi: 10.1046/j.1365-313X.2002.01385.x

Voznesenskaya, E., Koteyeva, N., Chuong, S., Akhani, H., Edwards, G., and Franceschi, V. (2005). Differentiation of cellular and biochemical features of the single-cell $\mathrm{C}_{4}$ syndrome during leaf development in Bienertia cycloptera (Chenopodiaceae). Am. J. Bot. 92, 1784-1795. doi: 10.3732/ajb.92.11.1784

Voznesenskaya, E. V., Akhani, H., Koteyeva, N. K., Chuong, S. D., Roalson, E. H., Kiirats, O., et al. (2008). Structural, biochemical, and physiological characterization of photosynthesis in two $\mathrm{C}_{4}$ subspecies of Tecticornia indica and the $\mathrm{C}_{3}$ species Tecticornia pergranulata (Chenopodiaceae). J. Exp. Bot. 59, 1715-1734. doi: 10.1093/jxb/ern028

Voznesenskaya, E. V., Koteyeva, N. K., Akhani, H., Roalson, E. H., and Edwards, G. E. (2013). Structural and physiological analyses in Salsoleae (Chenopodiaceae) indicate multiple transitions among $\mathrm{C}_{3}$, intermediate, and $\mathrm{C}_{4}$ photosynthesis. J. Exp. Bot. 64, 3583-3604. doi: 10.1093/jxb/ert191

Waha, K., Krummenauer, L., Adams, S., Aich, V., Baarsch, F., Coumou, D., et al. (2017). Climate change impacts in the Middle East and Northern Africa (MENA) region and their implications for vulnerable population groups. Reg. Environ. Change 17, 1623-1638. doi: 10.1007/s10113-017-1144-2

Walker, D., Lutts, S., Sánchez-García, M., and Correal, E. (2014). Atriplex halimus L.: Its biology and uses. J. Arid Environ. 100-101, 111-121. doi: 10.1016/ j.jaridenv.2013.09.004

Walker, J., Yang, Y., Feng, T., et al. (2018). From cacti to carnivores: Improved phylotranscriptomic sampling and hierarchical homology inference provide further insight into the evolution of Caryophyllales. Am. J. Bot. 105, 446-462. doi: 10.1002/ajb2.1069

Waller, S., and Lewis, J. (1979). Occurrence of $C_{3}$ and $C_{4}$ Photosynthetic Pathways in North American Grasses. J. Range Manage. 32, 12-28. doi: 10.2307/3897378

Wang, R., and Ma, L. (2016). Climate-driven $\mathrm{C}_{4}$ plant distributions in China: divergence in $\mathrm{C}_{4}$ taxa. Sci. Rep. 6, 27977. doi: 10.1038/srep27977

Wang, Y., Bräutigam, A., Weber, A. P. M., and Zhu, X. (2014). Three distinct biochemical subtypes of $\mathrm{C} 4$ photosynthesis? A modelling analysis. J. Exp. Bot. 65, 3567-3578. doi: 10.1093/jxb/eru058 
Welk, E. (2015). Phytogeography of the Nepalese flora and its floristic links to neighbouring regions. Nepal: An introduction to the natural history, ecology and human environment of the Himalayas. A companion volume to the Flora of Nepal (Edinburgh: Royal Botanic Garden Edinburgh), 140-144.

Wendrich, W. (1989). "Preliminary report on the Amarna basketry and cordage," in Amarna Reports. (London: Egypt Exploration Society), 169-201.

Whigham, D. F., Dykyjova, D., and Hejn, S. (1993). Wetlands of the world I lnventory, ecology, and management. Springer Sci. doi: 10.1007/978-94-015-8212-4

White, F., and Leonard, J. (1991). Phytogeographical links between Africa and Southwest Asia. Flora Vegetatio Mundi 9, 229-246.

Winter, K. (1981). C 4 plants of high biomass in arid regions of asia-occurrence of $\mathrm{C}_{4}$ photosynthesis in Chenopodiaceae and Polygonaceae from the Middle East and USSR. Oecologia 48, 100-106. doi: 10.1007/BF00346994

Wooler, M., Swain, D., Street-Perrot, E., Mathai, S., and Agnew, A. (2001). An Altitudinal And Stable Carbon Isotope Survey of $\mathrm{C}_{3}$ and $\mathrm{C}_{4}$ Graminoids On Mount Kenya. J. East Afr. Natural Hist. 90, 69-85. doi: 10.2982/0012-8317 (2001)90[69:AAASCI]2.0.CO;2

Zarrin, A., Ghaemi, H., Azadi, M., and Farajzadeh, M. (2009). The spatial pattern of summertime subtropical anticyclones over Asia and Africa: a climatological review. Int. J. Climatol. 30, 159-173. doi: 10.1002/joc.1879
Zarrin, A., Ghaemi, H., Azadi, M., Mofidi, A., and Mirzaei, E. (2011). The effect of the Zagros Mountains on the formation and maintenance of the Iran Anticyclone using RegCM4. Meteorol. Atmos. Phys. 112, 91-100. doi: 10.1007/s00703-011-0134-z

Zohary, M. (1973). Geobotanical foundations of the Middle East (Stuttgart: Fischer).

Zohary, M., and Hopf, M. (2000). Domestication of plants in the Old World. The Origin and Spread of Cultivated Plants in West Asia, Europe, and the Nile Valley. (Oxford: Oxford University Press), 316.

Conflict of Interest: The authors declare that the research was conducted in the absence of any commercial or financial relationships that could be construed as a potential conflict of interest.

Copyright (c) 2020 Rudov, Mashkour, Djamali and Akhani. This is an open-access article distributed under the terms of the Creative Commons Attribution License (CC BY). The use, distribution or reproduction in other forums is permitted, provided the original author(s) and the copyright owner(s) are credited and that the original publication in this journal is cited, in accordance with accepted academic practice. No use, distribution or reproduction is permitted which does not comply with these terms. 


\section{NOMENCLATURAL APPENDIX CHENOPODIACEAE}

Disintegration of Salsola s.l. into several lineages following molecular evidences lead to ample nomenclatural changes (Akhani et al., 2007). A major change was distinguishing Kali as a separate genus encompassing species of Salsola sect. Salsola with the type of Kali turgida (Dumort.) Guterm., (Gutermann, 2011). This system was accepted by many botanists and most nomenclatural changes were fixed according to the rules of International Code of Nomenclature (Hakobyan, 2011; Brullo et al., 2015; see additional notes and references in Sukhorukov et al., 2019). Two additional independent studies using one nuclear (ITS) and four plastid markers (atpB-rbcL spacer, $n d h \mathrm{~F}-r p l 32$ spacer, trnQ-rps 16 spacer, rpl16 intron) strongly confirmed the monophyly of Salsola s. str. sensu Akhani et al. (2007) (Voznesenskaya et al., 2013; Schüssler et al., 2017). A proposal to retypify the genus Salsola with Salsola kali by Mosyakin et al. (2014) did not get a consensus in Nomenclatural Committee (Applequist, 2016). However, in the last edition of the ICN, Salsola kali L. is accepted as the type of the genus Salsola (Turland et al., 2018). This unexpected decision necessitates several nomenclatural changes which we apply for those affected species occurring in the area of this paper.

Caroxylon omanense (Boulos) Akhani and Rudov comb. nov. Basionym: Salsola omanensis Boulos, Kew Bull. 46(2): 297 (1991).

Soda austro-iranica (Akhani) Akhani comb. nov. Basionym: Salsola austro-iranica Akhani in Pl. Veg. N. W. Persian Gulf 286 (2015).

Soda cyrenaica (Maire and Weiller) Akhani comb. nov. Basionym: Darniella cyrenaica Maire and Weiller, Bull. Soc. Hist. Nat. Afrique N. 1939, xxx. 301.

Soda drummondii (Ulbr.) Akhani comb. nov. Basionym: Nat. Pflanzenfam., ed. 2 [Engler and Prantl] 16c: 565 (1934).

Soda florida (M. Bieb.) Akhani comb. nov. Basionym: Anabasis florida M.Bieb., Fl. Taur.-Caucas. 1: 190 (1808).

Soda foliosa (L.) Akhani comb. nov. Basionym: Anabasis foliosa L., Sp. Pl. 1: 223 (1753).

Soda grandis (Freitag, Vural and N. Adiguzel) Akhani comb. nov. Basionym: Salsola grandis Freitag, Vural and Adıgüzel, Willdenowia 29(1-2): 131 (1999).

Soda cinerea (Moq.) Akhani comb. nov. Basionym: Halogeton? cinerea Moq., Chenopod. Monogr. 159 (1840).

Soda kerneri (Wol.) Akhani comb. nov. Basionym: Hypocylix kerneri Woł., Denkschr. Kaiserl. Akad. Wiss., Wien. Math.Naturwiss. Kl. 51(2): 276 (1886).
Soda longifolia (Forssk.) Akhani comb. nov. Basionym: Salsola longifolia Forssk., Fl. Aegypt.-Arab. 55. (1775).

Soda makranica (Freitag) Akhani comb. nov. Basionym: Salsola makranica Freitag, Fl. Iranica [Rechinger] 172: 166 (1997).

Soda oppositifolia (Desf.) Akhani comb. nov. Basionym: Salsola oppositifolia Desf., Fl. Atlant. 1: 219 (1798).

Soda rosmarinus (Ehrenb. ex Boiss.) Akhani comb. nov. Basionym: Seidlitzia rosmarinus Ehrenb. ex Boiss., Fl. Or. 4: 951, 1879.

Soda schweinfurthii (Solm.) Akhani comb. nov. Basionym: Salsola schweinfurthii Solms, Bot. Zeitung, 2. Abt. 59: 173, in obs. (1901).

Soda stocksii (Boiss.) Akhani comb. nov. Basionym: Salsola stocksii Boiss., Diagn. Pl. Orient. ser. 2, 4: 75 (1859).

\section{Poaceae}

The phylogenetic relationships within Poaceae has been investigated in several recent revisions (Hodkinson et al., 2002; Kellogg, 2015; Soreng et al., 2015; 2017). These revisions regarded also changes within the PACMAD clade, which includes all $\mathrm{C}_{4}$ Poaceae lineages. According to these revisions Pennisetum und Snowdenia has been synonymized with Cenchrus and Brachiaria (s.s.) with Urochloa. Several species have been however neglected by the taxonomic changes. We propose here new combinations for the following four species, that have been affected by the last revision by Soreng et al. (2017):

Cenchrus aethiopicus (Fresen.) Rudov comb. nov. Basionym: Beckera polystachya Fresen., Mus. Senckenberg. ii. 132 (1837).

Cenchrus glaucifolius (Hochst. ex A.Rich.) Rudov and Akhani comb. nov. Basionym: Pennisetum glaucifolium Hochst. ex A. Rich. Tent. Fl. Abyss. 2: 382 (1841).

Cenchrus nubicus (Hochst.) Rudov and Akhani comb. nov. Basionym: Gymnotrix nubica Hochst., Flora 27(1): 251 (1844).

Cenchrus yemensis (Deflers) Rudov and Akhani comb. nov. Basionym: Pennisetum yemense Deflers, Voyage Yemen 217 (1889).

Urochloa arida (Mez) Rudov comb. nov. Basionym: Panicum aridum Mez, Bot. Jahrb. Syst. 34(1): 139 (1905.

Urochloa chusqueoides (Hack.) Rudov comb. nov. Basionym: Panicum chusqueoides Hack., Bull. Herb. Boissier iii. 377 (1895).

Urochloa ovalis (Stapf) Rudov comb. nov. Basionym: Brachiaria ovalis Stapf, Fl. Trop. Afr. [Oliver et al.] 9(3): 546 (1919). 